\title{
Re-oligotrophication trajectories of macrophyte assemblages in Mediterranean coastal lagoons based on 17-year time-series
}

\author{
Ines Le Fur ${ }^{1, *}$, Rutger De Wit ${ }^{2}$, Martin Plus ${ }^{3}$, Jocelyne Oheix ${ }^{1}$, Valérie Derolez ${ }^{1}$, \\ Monique Simier ${ }^{1}$, Nathalie Malet ${ }^{4}$, Vincent Ouisse ${ }^{1}$ \\ ${ }^{1}$ MARBEC, Univ Montpellier, CNRS, Ifremer, IRD, CS 30171, 34203 Sète, France \\ ${ }^{2}$ MARBEC, Univ Montpellier, CNRS, Ifremer, IRD, CC093, 34095 Montpellier, France \\ ${ }^{3}$ Ifremer, Laboratoire d'écologie pélagique (DYNECO-PELAGOS), Centre Bretagne, ZI Pointe du Diable, CS 10070, \\ 29280 Plouzané, France
}

${ }^{4}$ Ifremer, Laboratoire Environnement Ressources Provence-Azur-Corse, station de Corse, Immeuble Agostini, Z.I. Furiani, 20600, Bastia, France

\begin{abstract}
Since the mid-20th century, Mediterranean lagoons have been affected by eutrophication, leading to significant changes in primary producers. In the early 2000s, management actions have been implemented to reduce nutrient inputs with the aim to achieve a good ecological status as requested by the EU water framework directive. As a result of these actions, a sharp decline in nutrient loads has been recorded in several lagoons leading to an oligotrophication of the water column. The analyses of a long-term data set (1998-2015) of 21 polyhaline and euhaline lagoons with contrasting trophic status allowed us to infer a general scheme for the changes in macrophyte assemblages during the oligotrophication process. Placing hypertrophic and oligotrophic conditions end to end, we inferred that the general pattern for the re-oligotrophication trajectory in Mediterranean coastal lagoons is described by the following sequence, with regime shifts between each state: (1) bare non-vegetated sediments, phytoplankton-dominated state; (2) opportunistic macroalgae; (3) seagrass and perennial macroalgae dominated state. However, we did not observe the latter regime shift for the most eutrophicated lagoons, which, so far, remained stuck in the opportunistic macroalgae state. So far, the shift from dominance of opportunistic macroalgae to a system dominated by seagrasses was only observed in a single lagoon where seagrasses had never completely disappeared, which possibly relates to resilience. More generally, the conditions favoring regime shifts from opportunistic macroalgae to seagrasses are still poorly understood. In conclusion, we describe a generic pattern for re-oligotrophication of Mediterranean coastal lagoons, although a full recovery from highly eutrophied to oligotrophic conditions may require more than a decade and may include conditions that remain so far poorly recognized.
\end{abstract}

KEY WORDS: Submerged aquatic vegetation - Recovery - Nutrient reduction - Restoration · Long-term data series $\cdot$ Resilience $\cdot$ Regime shift $\cdot$ Coastal lagoon

\section{INTRODUCTION}

Marine benthic macrophyte communities, including seagrasses and macroalgae, play a major structural and functional role in shallow coastal ecosystems such as estuaries and coastal lagoons. Marine macrophytes are among the most productive habitats

*Corresponding author: ines.le.fur@gmail.com on earth (Mann 1973) and play an important role in the ocean carbon budget (Duarte 1995, Duarte \& Cebrián 1996) and in other biogeochemical processes, e.g. nutrient cycles (Rysgaard et al. 1996, Flindt et al. 1999, Human et al. 2015). Furthermore, by reducing wave energy and water flow, submerged aquatic vegetation, particularly seagrasses,

(C) The authors 2019. Open Access under Creative Commons by Attribution Licence. Use, distribution and reproduction are unrestricted. Authors and original publication must be credited. 
increases the deposition of suspended matter and improves sediment stability (van der Heide et al. 2007 and references therein). Hence, submerged aquatic vegetation contributes to increase water transparency. Moreover, the uptake of nutrients, and the production of oxygen and its release into the water column (Romero et al. 2006), may reduce potential anoxic events. Macrophytes also represent an important food source and provide nurseries and foraging habitats for many species (e.g. invertebrates, fish, and birds). Hence, macrophytes create complex habitats and influence the physical, chemical and biological parameters of coastal environments by acting as ecological engineers and providing many ecosystem services (Costanza et al. 1997, Orth et al. 2006, Barbier et al. 2011).

Since the mid-20 ${ }^{\text {th }}$ century, human population growth, urbanization, agricultural and industrial expansion has led to significant nutrient over-enrichment of coastal ecosystems worldwide (Cloern 2001, de Jonge et al. 2002). This excess of nutrient loading has led to eutrophication, which has become a widespread phenomenon impacting water quality and ecological processes of marine coastal ecosystems (Nixon 1995). The major impacts of eutrophication include changes in the structure and functioning of marine ecosystems, reduction of biodiversity, as well as changes in the composition and size structure of phytoplankton communities (Bec et al. 2011) and sessile organisms such as benthic fauna (Lloret \& Marín 2011) and macrophytes. Concerning the latter point, the change of submerged aquatic vegetation along eutrophication gradients and its consequences on ecosystem functioning is well known (Harlin 1995, Valiela et al. 1997, Schramm 1999, Viaroli et al. 2008, Le Fur et al. 2018). During the eutrophication process, ephemeral epiphytic macroalgae and fast growing opportunistic macroalgae (e.g. Ulva, Chaetomorpha, Cladophora) gradually replace seagrasses and perennial macroalgae. Finally, under hypertrophic conditions, phytoplankton becomes the main primary producer, drastically reducing the available light for benthic photosynthesis (Duarte 1995, Schramm 1999, Viaroli et al. 2008). Phytoplankton and macroalgal blooms not only affect natural coastal communities and ecosystem functions (Duarte 1995), but have also high economic consequences for recreational and commercial uses (Charlier \& Lonhienne 1996, Dion \& Bozec 1996, Lyons et al. 2014).

Due to the widespread degradation of aquatic ecosystems, a number of policies have been implemented to mitigate the ecological and economic effects of eutrophication and to restore aquatic eco- systems by reducing anthropogenic nutrient inputs. In Europe, several directives have been adopted in order to reduce eutrophication and other anthropogenic pressures: the nitrate directive (91/676/EEC, in 1991); the urban wastewater treatment directive (91/271/EEC, in 1991); the water framework directive (WFD, 2000/60/EC, in 2000); and the marine strategy framework directive (MSFD, 2008/56/EC, in 2008). The aim of the WFD is to achieve a good ecological status of groundwater and surface waters (rivers, lakes, transitional and coastal waters; the latter 2 include the coastal lagoons) by 2021.

Management actions have been implemented to reduce nutrient loadings into coastal ecosystems in order to induce a re-oligotrophication trajectory and eventually restore the coastal ecosystems. The oligotrophication process, which is considered as the inverse of the eutrophication process, is defined as the response of the ecosystem to a reduction of nutrient loadings. The term 're-oligotrophication trajectory' is coined here for describing the trajectory of an ecosystem during the oligotrophication process following a previous eutrophication phase. During the last decades, the recovery of coastal ecosystems after nutrient reduction has received a growing interest in scientific studies (e.g. Tsiamis et al. 2013, Riemann et al. 2016, Leruste et al. 2016, Pasqualini et al. 2017, Lefcheck et al. 2018). Nevertheless, our understanding of re-oligotrophication trajectories remains limited. In addition, to quote the review of estuarine and coastal systems by Duarte et al. (2015, p. 1210):

... partial recovery prevails, degradation and recovery typically follow different pathways as buffers act to maintain the degraded state, and recovery trajectories can depend on the nature of the pressure as well as the connectivity of ecosystems and can differ among ecosystems components and among ecosystems ...

According to McCrackin et al. (2017), lakes and coastal marine areas only achieved $34 \%$ and $24 \%$ of baseline conditions decades after cessation or partial reduction of nutrients, respectively. In some cases no changes or worsened conditions were observed, suggesting that achieving baseline conditions may not be possible in all cases. Moreover, recovery times after cessation of nutrient inputs can vary from less than a year to nearly a century (Borja et al. 2010, McCrackin et al. 2017).

Due to their location between land and sea, their shallow depth and their relatively weak exchange with the open sea, coastal lagoons are particularly vulnerable to eutrophication (Barnes 1980, Kjerfve 1994, Kennish \& Paerl 2010). Ecological restoration of coastal lagoons following the reduction of nutrient 
loading is recent and studies of this process are still scarce (Facca et al. 2014, Leruste et al. 2016, Pasqualini et al. 2017). Due to the high variability and dynamics of these systems, restoration trajectories are expected to be variable and complex. During the oligotrophication process in Mediterranean lagoons, a decline in phytoplankton biomass is observed, accompanied by a shift in community structure and composition (Leruste et al. 2016). In noneutrophicated conditions, shallow lagoons tend to be dominated by benthic primary producers, such as seagrasses, macroalgae and benthic microalgae rather than phytoplankton (Lloret \& Marín 2009, Le Fur et al. 2018).

Studying the dynamics of changes in submerged aquatic vegetation requires large spatial scale and long-term observations that allow the description of trajectories in the ecosystem state space (Tett et al. 2013). In Southern France, nutrient reduction has been pursued in lagoon watersheds as part of public policy for the past 10 to $15 \mathrm{yr}$. We hypothesize that the reduction of nutrient availability causes a decrease in the phytoplankton biomass followed by a dynamic macrophyte succession pattern. This study, based on environmental and macrophyte data, aims (1) to determine the general patterns of the relationships between environmental conditions and macrophyte assemblages in Mediterranean lagoons, and (2) to study how the assemblages changed over time together with the environmental conditions, in order to gain a better understanding of the ecosystem state trajectories for the aquatic vegetation.

\section{MATERIALS AND METHODS}

\subsection{Study sites}

Our study covered 21 French Mediterranean coastal lagoons with salinities ranging from polyhaline to euhaline (Venice System, 1958). Most of these lagoons are located in the Gulf of Lion (NW Mediterranean Sea) and 3 of them are located along the east coast of Corsica (Tyrrhenian Sea) (Fig. 1). The studied lagoons are shallow water bodies; only 4 lagoons have a mean depth $>2 \mathrm{~m}$ : Leucate (the southern part), Thau, Diana, and Urbino (see Souchu et al. 2010, Bec et al. 2011 and Le Fur et al. 2018 for a

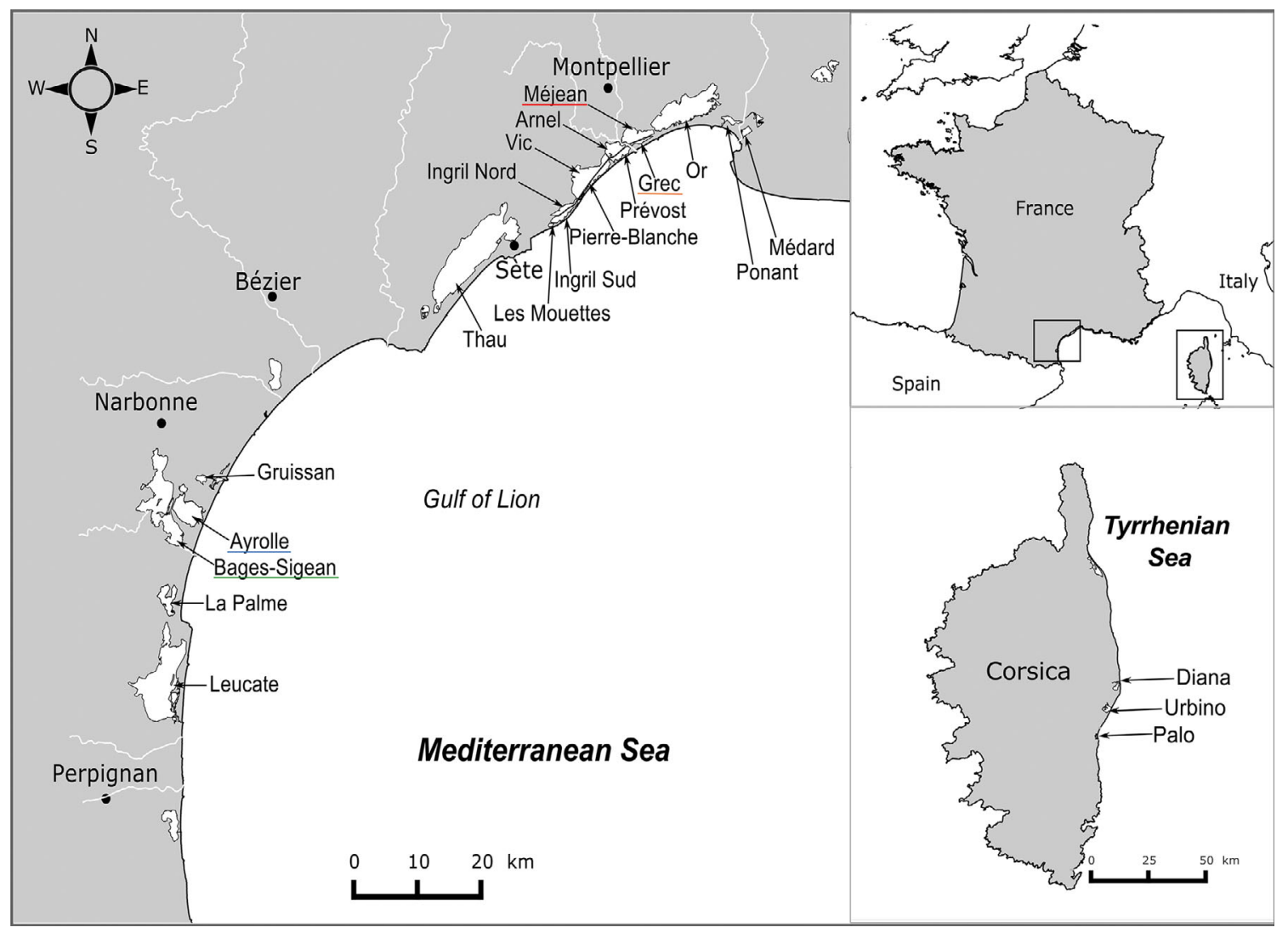

Fig. 1. Overview of the study area, showing the 21 polyhaline and euhaline lagoons of the French Mediterranean coast. Lagoons used to illustrate our study are underlined (Bages in green, Ayrolle in blue, Méjean in red and Grec in orange) 
more detailed overview of the catchment area characteristics of these lagoons). Some of these lagoons (i.e. Leucate, Bages, Thau, Prévost, Méjean, Or) were divided into hydrodynamically homogeneous sectors corresponding to sub-basins empirically defined on the basis of their bathymetry (Souchu et al. 2010). Hence, a total of 27 homogeneous sectors were defined within these 21 coastal lagoons. Over time, the 27 lagoon sectors experienced different trophic statuses ranging from oligotrophic to hypertrophic (Souchu et al. 2010, Le Fur et al. 2018).

Based on the analyses of the results, a set of lagoons was selected to study re-oligotrophication trajectories in more detail. The criteria for this selection of lagoons were the following: (1) lagoons showing clear re-oligotrophication trends when their starting conditions were hypertrophic to eutrophic; (2) lagoons where specific management has been implemented for the reduction of nutrient loading, or oligotrophic lagoons that had been minimally impacted by anthropogenic nutrient loading; (3) lagoons collectively representing a set of conditions ranging from hypertrophic to oligotrophic. The objective was to describe a generic trajectory from hypertrophy to oligotrophy during re-oligotrophication.

\subsection{Sampling methods}

\subsubsection{Water column}

Sampling methodology and analyses of the water column variables were consistent throughout the entire monitoring period 1998-2015. We considered 7 variables from the database: the turbidity (TURB), the concentrations of chlorophyll a ( $\mathrm{chl} a)$, total nitrogen (TN), total phosphorus (TP), and the concentrations of ammonium $\left(\mathrm{NH}_{4}\right)$, sum of nitrate plus nitrite $\left(\mathrm{NO}_{3}+\mathrm{NO}_{2}\right)$ and phosphate $\left(\mathrm{PO}_{4}\right)$. TN and TP include dissolved organic and inorganic nitrogen and phosphorus, respectively, plus their particulate forms. Sampling was carried out 3 times (i.e. once per month from June to August) every year at 1 station per lagoon sector (see Table S1 in Le Fur et al. 2018). On each date, water was collected with 2-1 polypropylene bottles. Turbidity was measured in the laboratory with an optic turbidimeter (2100N IS turbidimeter ISO 7027). Chl a concentration, used as a proxy for phytoplankton biomass, was measured by spectrofluorimetry (Neveux \& Lantoine 1993). Filtration, conservation and analysis of chl a concentrations were performed following the methods described in Bec et al.
(2011), and nutrients concentrations were measured following the analytical protocols described in Souchu et al. (2010).

\subsubsection{Sediment}

Sediment cores were taken by scuba diving (in late spring or early summer) at each benthic station with a frequency of once every 5 or 6 yr from 1999 to 2012. The first centimeters $(0-5 \mathrm{~cm})$ of the sediment were collected with a sediment core and then sifted through a $2 \mathrm{~mm}$ sieve (Ifremer et al. 2000). Organic matter content (OM, expressed as \% of dry sediment weight) was calculated as the loss of weight on ignition of $20 \mathrm{ml}$ of dry sediment placed into a muffle furnace at $450^{\circ} \mathrm{C}$ for $12 \mathrm{~h}$. Total nitrogen in the sediment (TNsed) was analyzed with a Thermoquest CN 2100. Total phosphorus in the sediment (TPsed) was measured through colorimetry as phosphate (Souchu et al. 2010) after dissolution and hydrolysis. For this, sediment samples were mixed with a solution of nitric, hydrofluoric and perchloric acids. The solution obtained was then evaporated and dissolved in hydrochloric acid. TNsed and TPsed concentrations were expressed in $\mathrm{g} \mathrm{kg}^{-1}$ and $\mathrm{mg} \mathrm{kg}^{-1}$ dry sediment, respectively, with a precision of $5 \%$.

\subsubsection{Benthic vegetation}

All 27 lagoon sectors were monitored for benthic vegetation from 1998 to 2015 using a sampling frequency of once every 3 or 4 yr. For further details about the monitoring surveys, see the supplementary material in Le Fur et al. (2018). The macrophyte samplings were performed at benthic stations; the number of benthic stations and sampling frequency for each lagoon is available in Le Fur et al. (2018), Table S1 of the supplementary material. Macrophyte sampling campaigns were carried out in late spring or early summer during the maximal growth and production rates. The benthic stations were located following a regular systematic grid with 1 station for every 100 ha for large lagoons (surface area exceeding 1000 ha) and 1 station for every 50 ha for smaller lagoons. The benthic stations of the deepest lagoons were sampled by scuba diving, and those of the shallowest lagoons were sampled by snorkeling. Total vegetation cover was estimated visually by the diver at each benthic station. The method to estimate the proportional abundance of the different species in the assemblages changed during the monitoring pro- 
gram. Thus, from 1998 to 2006, the biomasses of the different species were measured in the laboratory as dry weight. From 2007 onwards, the species cover was visually estimated directly in the field by divers (see Le Fur et al. 2018 for more details of the methodology). These different methods were intercalibrated in the first year after the change. The comparison of the results made it possible to show an equivalence of the lists of species recorded by both methods. More details of the methodology are provided in Le Fur et al. (2018).

At each benthic station, macrophyte samples were collected and identified in the laboratory. Macrophytes were sorted and identified using a binocular microscope and a light microscope. The taxonomic resolution of macrophyte determinations was at species level when possible. Taxonomic nomenclature followed AlgaeBase (Guiry \& Guiry 2016) and World Register of Marine Species (WoRMS Editorial Board 2016).

\subsection{Statistical analysis}

\subsubsection{Data format}

The data used in this study were extracted from the French database 'Quadrige' (Ifremer, http://quadrige. eaufrance.fr/). Data concerning the water column are available via the open data file: www.seanoe.org/ data/00361/47248/.

Presence-absence data for each species were used for the macrophytes, due to the heterogeneity of the sampling methods. In addition, a supplementary variable labelled as 'bare sediment' was introduced to characterize sediment without macrophytes. The relative frequencies for the different species (and bare sediment) were calculated by dividing the number of occurrences by the total number of benthic stations in each lagoon sector for each sampling year.

The water column samples were not collected exactly at the same period as the macrophyte samples, and thus it would not have been correct to directly associate the macrophyte data with the environmental variables. We assumed that the presence-absence of a given species in a sector is not exclusively explained by the environmental condition of the sampling year ' $k$ ', but also by the conditions prevailing during the previous 2 yr (particularly for perennial species). Therefore, the macrophyte samplings of the year ' $k$ ' were associated with the mean summer values of each environmental variable integrated over a period of $3 \mathrm{yr}(k, k-1, k-2)$.

\subsubsection{Multivariate STATICO analysis and other tests}

The objective of the present study was to establish a statistically meaningful link between environmental conditions and the presence of macrophyte species and their variations over time. The structure of the data comprised a series of paired data tables (see Fig. 2), i.e. one table with the presence-absence of species, and another table with the environmental conditions. These can be analyzed pairwise through different techniques including canonical correspondence analysis (CCA), redundancy analysis (RDA) or the multitable analysis method STATICO (Simier et al. 1999, Thioulouse et al. 2004). Among these, we chose STATICO as it represented the following advantages. Firstly, STATICO does not require an a priori model describing the relationship between the occurence of the different species and environmental conditions, which is assumed to be unimodal in CCA and linear in RDA. Secondly, STATICO maximizes the covariance instead of calculating a correlation. Thus, the information of the sampling data is explicitly maintained in the analyses. Thirdly, STATICO is capable of giving different weights to pairs of tables and is thus able to weight down tables with minor contributions to the main patterns. These advantages are related to the mathematical optimality theorems of STATICO (Thioulouse et al. 2004). STATICO thus calculates a species-environment relation for each sampling occasion and is, therefore, very well suited for describing long-term changes in the species environment relationships (Mendes et al. 2012).

To implement the STATICO analysis we created for each sampling year ( $k$ ranging from 1 to 16 , from 1998 to $2015 ; K=$ total number of years equal to 16 ), a pair of 2 tables, i.e. a table ( $Y$ ) with columns for the 7 environmental variables and another table $(X)$ with columns for the 105 species and the additional variable 'bare sediment'. Both environment and species tables have 27 rows, which correspond to the number of lagoon sectors (Fig. 2). STATICO analysis was performed on the set of $K=16$ pairs of tables ( $X$ and $Y$ ). The STATICO method involves 3 steps (Fig. 2): (1) each table is first analyzed using a principal component analysis (PCA) for the environmental tables and a correspondence analysis (CA) for the species tables; (2) each pair of tables is linked by a co-inertia analysis (Dolédec \& Chessel 1994) which provides an image of the common structure (resulting in speciesvariables cross table $Z$ ) for each year; (3) partial triadic analysis (PTA) is used to analyze the series of $K$ cross tables. The PTA itself is a 3-step procedure: (i) the interstructure; (ii) the compromise factor map; 

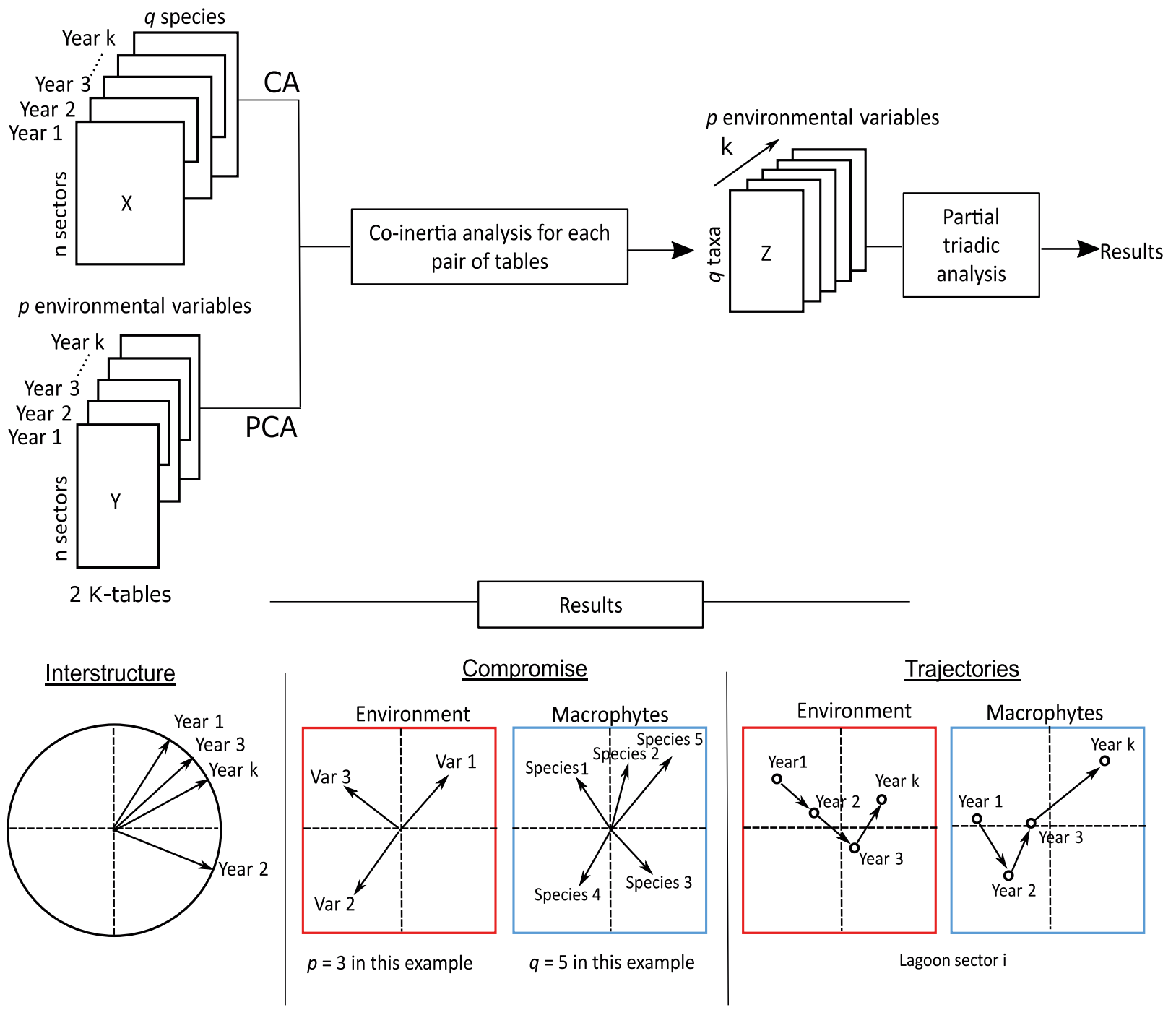

Fig. 2. STATICO diagram, the data structure is a sequence of $k$ pairs of ecological tables. The $X$ and $Y$ are the tables of the species and environmental variables, respectively. $Z$ indicates the cross tables, $\mathrm{n}$ the number of lagoon sectors, $q$ the number of species, $p$ the number of environmental variables. Lagoon sector $\mathrm{i}$ is one sector out of $\mathrm{n}$. Figure modified from Kidé et al. (2015)

and (iii) the trajectories analysis. The interstructure step summarizes the global structure and the relationship between the $K$ cross tables and computes coefficients characterizing the importance of each table. The next step computes a weighted mean of the $K$ cross tables (using the coefficients computed at the interstructure step) and gives an image of their common structure. This is presented as the STATICO compromise factor map, an $n$-dimensional space. This compromise factor map can thus be considered as a factorial representation of the ecosystem state space for the collection of coastal lagoon sectors included in the analysis. Species assemblages and environmental variables corresponding to the different samplings can then be plotted in the compromise factor map, allowing an analysis of trajectories for the different lagoon sectors. Hence, the temporal dynamics of the species-environment co-structure (trajectories) can be interpreted in terms of changes of the ecosystem state. Sediment data were not included in the STATICO analysis due to a lower sampling frequency.

The trajectories of the selected lagoons (see criteria for selection in 'Study site') are depicted together in the compromise factor map. The 7 water column parameters of the selected lagoon sectors were compared before and after implementation of the main management actions using the non-parametric Wilcoxon test. For the sediment, Kruskal-Wallis and pairwise Wilcoxon tests were used to identify significant differences of OM, TNsed, and TPsed between lagoon sectors and between periods, respectively. 


\subsubsection{Software}

All analyses were performed using R software (version 3.1.1; R Core Team 2018). Calculations and graphs shown for the STATICO analyses were done using the ade4 package (Dray \& Dufour 2007).

\section{RESULTS}

\subsection{Relationships between environment and macrophyte assemblages and their change over time}

The 17 most frequently occurring species (occurrence $>5 \%$ in the grand ensemble of all samples) are presented in Table 1 and comprised 10 species of Chlorophyta (3 species of Ulva, 2 species of Cladophora, 2 species of Chaetomorpha, and 3 others), 4 species of Rhodophyta (among these 3 Gracilaria species), and 3 Tracheophyta. The latter are rooted angiosperms and included the 2 seagrasses Zostera noltei and $Z$. marina, and the spiral ditch grass Ruppia cirrhosa.

The interstructure step of the STATICO analyses showed that the first 2 axes of the interstructure represented $29.6 \%$ and $17.0 \%$ of the total variability, respectively (see Fig. S1 in the Supplement at www.int-res.com/articles/suppl/m608p013_supp.pdf). The 16 tables were positively correlated, i.e. all the years were on the same side along the first axis. The construction of the compromise factor map was thus justified. Among the 16 years, 2002, 2004, 2006 and
2013 were the most important (highest $\cos ^{2}$ and weights; Fig. S1) for defining the compromise factor map. This means that the relationship between environmental variables and assemblages of macrophyte species were strongest during those years (see Fig. S1 for further details).

The findings of the interstructure step thus allowed us to calculate a weighted mean of the relationship between species and environmental conditions among dates, i.e. the compromise factor map of the STATICO analysis shown in Fig. 3. The scree plot indicating the eigenvalues for the different factors is shown in Fig. 3c, which shows that the first axis was clearly dominant, explaining $88.5 \%$ of the total variability, the second axis still explained $9.5 \%$ of the total variability, while the following axes could be neglected (i.e. less than $2 \%$ of the total variability explained). Hence, hereafter, we will only use the first 2 axes and represent the STATICO space as a plane.

The projection of the environmental variables and the macrophyte species in the assemblage are shown in Fig. 3a and 3b, respectively. TN, TP, chl $a$ and turbidity variability are shown along the first axis of the analysis (see Fig. 3a), with high values located on the left side and low values on the right side of this axis. This first axis represents, therefore, a trophic gradient with hypertrophic conditions on the left and oligotrophic conditions on the right. Dissolved inorganic nutrient variability is shown on the second axis, with higher concentrations towards the bottom of the graph.

The projection of the species in the compromise factor map (Fig. 3b) shows that macrophyte species

Table 1. Species and their abbreviations used in the multivariate analysis (STATICO)

\begin{tabular}{|c|c|c|c|c|}
\hline Phylum & Genus & Species & Abbreviation & Taxonomist \\
\hline \multirow[t]{10}{*}{ Chlorophyta } & Acetabularia & Acetabularia acetabulum & A. acetabulum & (Linnaeus) P. C. Silva, 1952 \\
\hline & \multirow[t]{2}{*}{ Chaetomorpha } & Chaetomorpha aerea & C. aerea & (Dillwyn) Kützing, 1849 \\
\hline & & Chaetomorpha linum & C. linum & (O. F. Müller) Kützing, 1845 \\
\hline & \multirow[t]{2}{*}{ Cladophora } & Cladophora glomerata & C. glomerata & (Linnaeus) Kützing, 1843 \\
\hline & & Cladophora vagabunda & C. vagabunda & (Linnaeus) van den Hoek, 1963 \\
\hline & \multirow[t]{3}{*}{ Ulva } & Ulva clathrata & U. clathrata & (Roth) C. Agardh, 1811 \\
\hline & & Ulva intestinalis & U. intestinalis & Linnaeus, 1753 \\
\hline & & Ulva rigida & U. rigida & C. Agardh, 1823 \\
\hline & Ulvaria & Ulvaria obscura & U. obscura & (Kützing) P. Gayral ex C. Bliding, 1969 \\
\hline & Valonia & Valonia aegagropila & V. aegagropila & C. Agardh, 1823 \\
\hline \multirow[t]{4}{*}{ Rhodophyta } & \multirow{4}{*}{$\begin{array}{l}\text { Chondria } \\
\text { Gracilaria }\end{array}$} & Chondria capillaris & C. capillaris & (Hudson) M. J. Wynne, 1991 \\
\hline & & Gracilaria bursa-pastoris & G. pastoris & (S. G. Gmelin) P. C. Silva, 1952 \\
\hline & & Gracilaria dura & G. dura & (C. Agardh) J. Agardh, 1842 \\
\hline & & Gracilaria gracilis & G. gracilis & $\begin{array}{l}\text { (Stackhouse) M. Steentoft, } \\
\text { L. M. Irvine \& F. Farnham, } 1995\end{array}$ \\
\hline \multirow[t]{3}{*}{ Tracheophyta } & \multirow{3}{*}{$\begin{array}{l}\text { Ruppia } \\
\text { Zostera }\end{array}$} & Ruppia cirrhosa & R. cirrhosa & (Petagna) Grande, 1918 \\
\hline & & Zostera marina & Z. marina & Linnaeus, 1753 \\
\hline & & Zostera noltei & Z. noltei & Horneman, 1832 \\
\hline
\end{tabular}



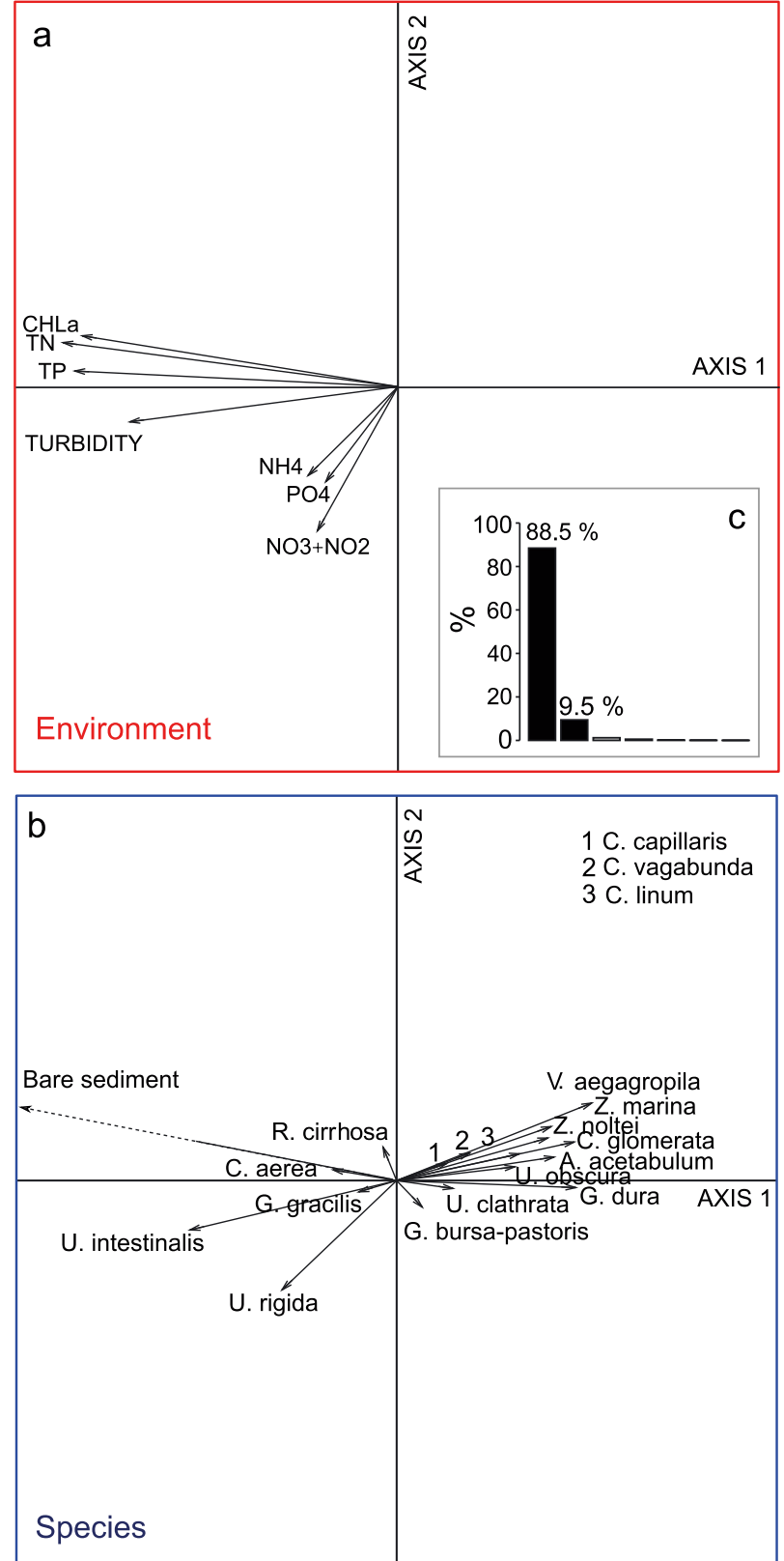

Fig. 3. Compromise factor map of the STATICO analysis taking into account the 27 lagoon sectors. (a) Projection of the environmental variables (variable codes are given in 'Materials and methods'), and (b) projection of the macrophyte species. (c) Scree plot of eigenvalues for the different factors. The superimposition of the 2 maps provides information about the stable part of the relationships between environmental variables and macrophytes species. Note that (b) has been enlarged in order to give a better view of the species

were distributed along a trophic gradient. The green algae Ulva intestinalis, U. rigida, Chaetomorpha aerea, and the red algae Gracilaria gracilis were projected on the graph's left side, corresponding to high $\mathrm{TN}, \mathrm{TP}, \mathrm{chl}$ a concentrations and a high turbidity level, whereas species such as the macroalgae Acetabularia acetabulum, Valonia aegagropila, and the seagrasses $Z$. marina and $Z$. noltei were projected on the right side, corresponding to lagoon sectors with low nutrient and chl a concentrations as well as low turbidities (Fig. 3b). The position of U. rigida (lower left) corresponded to eutrophic environments with high levels of dissolved inorganic nutrient concentrations. The position of the variable 'bare sediment' on the far-left of axis 1 indicates the absence of macrophytes and corresponded to hypertrophic conditions characterized by the highest levels of TN and TP, chl $a$ and turbidity (Fig. 3a,b).

\subsection{Trajectories of lagoons}

The projection of the trajectories over time in the compromise factor map, both for the environmental conditions and the species compositions of the macrophyte assemblages, are shown for all studied lagoon sectors in the Supplement (Fig. S2). We classified these trajectories into 5 different categories (Table 2). seven lagoons showed clear trajectories while other lagoons showed few dynamics. A stable trophic status has been attributed to the latter set of lagoons. Hence, we found a stable oligotrophic status for 7 lagoons, a mesotrophic status for 4 lagoons and an eutrophic status for 1 lagoon. In 2015, none of the lagoons showed a hypertrophic status. Seven lagoons showed welldefined dynamics: 6 lagoons (Méjean, Grec, the northern basin of Bages [BGN], Ingril, Arnel and Ponant) showed a trajectory from left to right, a re-oligotrophication trajectory, and only 1 lagoon (PierreBlanche) from right to left, a eutrophication trajectory. Among these lagoons with well-defined dynamics, 2 (Méjean and Grec) showed hypertrophic conditions in the early 2000s and showed improvement, without achieving oligotrophic status in 2015.

\subsection{Re-oligotrophication trajectories of selected lagoons plotted in the compromise factor map}

Based on criteria, 3 lagoons (Méjean, Grec and Bages) were selected to illustrate re-oligotrophication trajectories. The oligotrophic Ayrolle lagoon (AYR), little exposed to anthropogenic pressure, was selected as a reference lagoon. These 4 lagoons were plotted together in the compromise factor map (Fig. 3). The context of the selected lagoons was described (Table 3), and average values and 2-way comparisons for water column variables before and 
after the implementation of the management actions targeting nutrient reduction were provided (Table 4). Before their implementation, the western part of Méjean lagoon (MEW) and Grec lagoon (GRC) were among the most heavily degraded lagoons on the French Mediterranean coast and classified as hypertrophic (Souchu et al. 2010). The northern sector of the Bages lagoon (BGN) is hydrodynamically confined (Fiandrino et al. 2017) and used to be exposed to high nutrient loading from wastewater discharges and was classified as eutrophic (Ifremer 2007). Since the end of 2005 both Méjean and Grec lagoons have benefitted from the improvement of the waste water treatment plant (WWTP) of the Montpellier urban area and the diversion of its effluents through an offshore outfall (Leruste et al. 2016). Moreover, stopping the discharge from the WWTP of the village of Palavas (a smaller facility) into Grec lagoon in 2009, led to an additional improvement for this lagoon. For
Méjean and Grec lagoons together, the estimated reductions of nitrogen and phosphorus loadings were $92 \%$ and $95 \%$, respectively. In Bages lagoon improvement has progressed since 2003, resulting in a reduction of nitrogen $(85 \%)$ and phosphorus $(90 \%)$ loadings between 2002 and 2009 (Table 4).

Fig. 4 shows hypertrophic conditions for Grec (GRC) and Méjean West (MEW), and eutrophic conditions for Bages North (BGN) at the beginning of the observation period, and re-oligotrophication since the implementation of management actions. During the entire monitoring period, Ayrolle lagoon (AYR) showed the lowest values for all variables (TN, TP, chl $a, \mathrm{NO}_{3}+\mathrm{NO}_{2}, \mathrm{NH}_{4}, \mathrm{PO}_{4}$, Turbidity), confirming that this lagoon can be used as an oligotrophic reference state.

The possibility of combining the different re-oligotrophication trajectories to deduce a generic pattern will be discussed in the 'Discussion' section. Here-

Table 2. Classification of lagoon sector trajectories according to the STATICO analysis. Note that Diana (DIA) was excluded from the table because of incoherent trajectory between environmental conditions and species

\begin{tabular}{|c|c|}
\hline Category & Sector(s) \\
\hline Re-oligotrophication trajectory & $\begin{array}{l}\text { Bages Northern basin (BGN), Ingril (INN, INS), Arnel (ARN), Méjean (MEW, MEE), Grec } \\
\text { (GRC), Ponant (PON) }\end{array}$ \\
\hline Eutrophication trajectory & Pierre-blanche (PBL) \\
\hline Oligotrophic status & $\begin{array}{l}\text { Ayrolle (AYR), La Palme (LAP), Bages Southern basin (BGM, BGS), Leucate (LEN, LES), } \\
\text { Thau (TW, TE), Mouettes (MOU), Urbino (URB) }\end{array}$ \\
\hline Mesotrophic status & Gruissan (GRU), Vic (VIC), Prévost (PRW, PRE), Palo (PAL) \\
\hline Eutrophic status & Or (ORW, ORE) \\
\hline
\end{tabular}

Table 3. Characteristics of the 4 lagoons used to illustrate our study. The trophic status at the beginning of the study period is specified from Souchu et al. 2010. *: In Bages lagoon, nutrients (N, P) from a waste water treatment plant (WWTP) were estimated in 2002 and 2009 by the Parc Naturel Régional de la Narbonnaise (PNR 2011); in MEW and GRC nutrients from a WWTP were estimated from French Water Agency in 2003 (Cépralmar et al. 2006) and 2010 (Meinesz et al. 2013)

\begin{tabular}{|c|c|c|c|c|}
\hline & \multicolumn{4}{|c|}{ Lagoon sector } \\
\hline & Méjean West & Grec & Bages North & Ayrolle \\
\hline Code & MEW & GRC & BGN & AYR \\
\hline Initial trophic status (before management actions) & Hypertrophic & Hypertrophic & Eutrophic & Oligotrophic \\
\hline Watershed area $\left(\mathrm{km}^{2}\right)$ & 661.9 & 661.9 & 466.8 & 34.7 \\
\hline Lagoon area $\left(\mathrm{km}^{2}\right)$ & 7.2 & 1.2 & 37.7 & 13.4 \\
\hline Volume $\left(10^{6} \mathrm{~m}^{3}\right)$ & 4.1 & 0.7 & 48.2 & 9.9 \\
\hline Mean depth (m) & 0.7 & 0.5 & 1.5 & 0.7 \\
\hline Connection to the sea & Indirect & Indirect & $\begin{array}{c}\text { Direct: } \\
\text { permanent inlet }\end{array}$ & $\begin{array}{l}\text { Direct: natural } \\
\text { permanent inlet }\end{array}$ \\
\hline Main freshwater sources & Canal & River, canal & $\begin{array}{l}\text { Intermittent } \\
\text { streams, canals }\end{array}$ & $\begin{array}{c}\text { Temporary } \\
\text { resurgence, wetland }\end{array}$ \\
\hline Major management actions & 2005 & 2005 & 2003 & \\
\hline Minor management actions & & 2009 & 2005,2009 & \\
\hline \multicolumn{5}{|l|}{ Estimation of domestic nutrient inputs*: } \\
\hline $\mathrm{N}\left(\mathrm{t} \mathrm{N} \times \mathrm{yr}^{-1}\right)$ before and (after) management actions & \multicolumn{2}{|c|}{1436 (118) } & $291(43)$ & 0 \\
\hline $\mathrm{P}\left(\mathrm{t} \mathrm{P} \times \mathrm{yr}^{-1}\right)$ before and (after) management actions & \multicolumn{2}{|c|}{$123(6.6)$} & $47(4.5)$ & 0 \\
\hline
\end{tabular}


Table 4. Statistics of water column variables during the study period (1999-2015) for 4 representative lagoon sectors (Ayrolle [AYR], Bages North [BGN], Grec [GRC], and Méjean West [MEW]). The values before (B) and after (A1, A2) management actions were tested with a Wilcoxon-Mann-Whitney test between 2 groups. In GRC, to compare the differences between the 3 management action periods, a Kruskal-Wallis test followed by a pairwise Wilcoxon test was used. Letters in the p-value column indicate between which periods a significant difference was observed. TN: total nitrogen $(\mu \mathrm{M})_{i}$ TP: total phosphorus $(\mu \mathrm{M}) ;$ chl a: chlorophyll $a_{i} \mathrm{NH}_{4}$ : ammonium $(\mu \mathrm{M}) ; \mathrm{NO}_{3}+\mathrm{NO}_{2}$ : nitrate + nitrite $(\mu \mathrm{M}){ }_{i} \mathrm{PO}_{4}$ : phosphate $(\mu \mathrm{M})$; TURB: turbidity $(\mathrm{NTU}) .{ }^{*} \mathrm{p}<0.05$

\begin{tabular}{|c|c|c|c|c|c|c|}
\hline $\begin{array}{l}\text { Variable and } \\
\text { lagoon sector }\end{array}$ & \multicolumn{2}{|c|}{$\begin{array}{l}\text { Period before/ } \\
\text { after MA }\end{array}$} & Mean & $\mathrm{SD}$ & $\mathrm{N}$ & $\mathrm{p}$ \\
\hline \multicolumn{7}{|l|}{ TN } \\
\hline AYR & & & 31.9 & 11.1 & 49 & \\
\hline \multirow{2}{*}{ BGN } & 1999-2003 & B & 54.4 & 15.0 & 12 & $<0.001^{*}$ \\
\hline & $2004-2015$ & A1 & 38.7 & 8.07 & 36 & \\
\hline \multirow[t]{3}{*}{ GRC } & 1999-2005 & B & 216 & 80.9 & 19 & $<0.001^{*}$ \\
\hline & $2006-2009$ & A1 & 142 & 120 & 11 & $\mathrm{~B}-\mathrm{A} 1, \mathrm{~B}-\mathrm{A} 2, \mathrm{~A} 1-\mathrm{A} 2$ \\
\hline & 2010-2014 & A2 & 55.6 & 21.6 & 15 & \\
\hline \multirow[t]{2}{*}{ MEW } & $2000-2005$ & $\mathrm{~B}$ & 334 & 110 & 16 & $<0.001^{*}$ \\
\hline & $2006-2015$ & A1 & 104 & 69.2 & 30 & \\
\hline \multicolumn{7}{|c|}{$2000-2015$} \\
\hline \multirow{3}{*}{$\begin{array}{l}\text { AYR } \\
\text { BGN }\end{array}$} & & & 0.69 & 0.26 & 49 & \\
\hline & 1999-2003 & B & 3.22 & 1.93 & 12 & $<0.001^{*}$ \\
\hline & $2004-2015$ & A1 & 1.34 & 0.60 & 36 & \\
\hline \multirow[t]{3}{*}{ GRC } & 1999-2005 & B & 12.0 & 6.58 & 19 & $<0.001^{*}$ \\
\hline & $2006-2009$ & A1 & 6.21 & 6.49 & 11 & $\mathrm{~B}-\mathrm{A} 1, \mathrm{~B}-\mathrm{A} 2$ \\
\hline & $2010-2014$ & A2 & 3.47 & 2.17 & 15 & \\
\hline \multirow[t]{2}{*}{ MEW } & $2000-2005$ & B & 19.2 & 1.58 & 16 & $<0.001^{*}$ \\
\hline & $2006-2015$ & $\mathrm{~A} 1$ & 7.87 & 5.41 & 30 & \\
\hline \multicolumn{7}{|l|}{ Chl a } \\
\hline AYR & & & 1.07 & 0.83 & 49 & \\
\hline \multirow[t]{2}{*}{ BGN } & 1999-2003 & B & 7.16 & 5.56 & 12 & $0.004^{*}$ \\
\hline & 2004-2015 & A1 & 3.58 & 3.42 & 36 & \\
\hline \multirow[t]{3}{*}{ GRC } & 1999-2005 & B & 128 & 85.3 & 19 & $<0.001^{*}$ \\
\hline & 2006-2009 & A1 & 52.3 & 106 & 11 & $\mathrm{~B}-\mathrm{A} 1, \mathrm{~B}-\mathrm{A} 2$ \\
\hline & $2010-2014$ & A2 & 7.08 & 6.63 & 15 & \\
\hline \multirow[t]{2}{*}{ MEW } & $2000-2005$ & B & 185 & 131 & 16 & $<0.001^{*}$ \\
\hline & $2006-2015$ & A1 & 19.8 & 28.1 & 30 & \\
\hline \multicolumn{7}{|l|}{$\mathrm{NH}_{4}$} \\
\hline AYR & & & 0.49 & 0.29 & 49 & \\
\hline BGN & 1999-2003 & B & 0.85 & 0.99 & 12 & 0.125 \\
\hline & 2004-2015 & A1 & 0.61 & 0.84 & 36 & \\
\hline GRC & $1999-2005$ & B & 20.7 & 24.1 & 19 & $0.002^{*}$ \\
\hline & 2006-2009 & A1 & 36.0 & 42.7 & 11 & $\mathrm{~B}-\mathrm{A} 2, \mathrm{~A} 1-\mathrm{A} 2$ \\
\hline & 2010-2014 & A2 & 1.12 & 1.53 & 15 & \\
\hline MEW & 2000-2005 & B & 1.90 & 3.40 & 16 & 0.230 \\
\hline & 2006-2015 & A1 & 1.68 & 3.23 & 30 & \\
\hline $\mathrm{NO}_{3}+\mathrm{NO}_{2}$ & & & & & & \\
\hline $\begin{array}{l}\text { AYR } \\
\text { BGN }\end{array}$ & 1999-2003 & B & $\begin{array}{l}0.14 \\
0.45\end{array}$ & $\begin{array}{l}0.12 \\
0.76\end{array}$ & $\begin{array}{l}49 \\
12\end{array}$ & 0.453 \\
\hline BGN & $2004-2015$ & A1 & 0.38 & 0.45 & 36 & \\
\hline GRC & 1999-2005 & $\mathrm{B}$ & 4.68 & 5.06 & 19 & $<0.001^{*}$ \\
\hline & 2006-2009 & A1 & 5.20 & 5.42 & 11 & $\mathrm{~B}-\mathrm{A} 2, \mathrm{~A} 1-\mathrm{A} 2$ \\
\hline & 2010-2014 & A2 & 0.22 & 0.19 & 15 & \\
\hline MEW & $2000-2005$ & $\mathrm{~B}$ & 0.41 & 1.58 & 16 & 0.390 \\
\hline & $2006-2015$ & A1 & 0.28 & 0.32 & 30 & \\
\hline $\mathrm{PO}_{4}$ & & & & & & \\
\hline AYR & & & 0.10 & 0.15 & 49 & \\
\hline BGN & 1999-2003 & B & 1.47 & 1.61 & 12 & $0.005^{*}$ \\
\hline & 2004-2015 & A1 & 0.29 & 0.49 & 36 & \\
\hline GRC & 1999-2005 & B & 2.25 & 5.06 & 19 & $0.007^{*}$ \\
\hline & 2006-2009 & A1 & 0.63 & 1.21 & 11 & $\mathrm{~A} 1-\mathrm{A} 2$ \\
\hline & 2010-2014 & A2 & 1.17 & 1.23 & 15 & \\
\hline MEW & $2000-2005$ & B & 1.59 & 6.36 & 16 & 0.090 \\
\hline & $2006-2015$ & A1 & 2.41 & 1.69 & 30 & \\
\hline TURB & & & & & & \\
\hline AYR & & & 1.53 & 1.26 & 49 & \\
\hline BGN & 1999-2003 & B & 2.74 & 1.41 & 12 & 0.088 \\
\hline & 2004-2015 & A1 & 3.52 & 1.80 & 36 & \\
\hline GRC & 1999-2005 & B & 22.4 & 12.2 & 19 & $0.003^{*}$ \\
\hline & $2006-2009$ & A1 & 23.3 & 32.3 & 11 & $\mathrm{~B}-\mathrm{A} 2$ \\
\hline & 2010-2014 & A2 & 8.26 & 5.49 & 15 & \\
\hline MEW & 2000-2005 & B & 27.1 & 12.8 & 16 & $0.001^{*}$ \\
\hline & $2006-2015$ & A1 & 15.0 & 11.6 & 30 & \\
\hline
\end{tabular}

after, the trajectories of the 4 lagoons (GRC, MEW, BGN, AYR) will be assessed in more detail, illustrating them by timeseries of their water column variables, vegetation cover and biomasses (Figs. 5 \& 6). The position of the oligotrophic AYR in the compromise factor map was systematically in the upper right part, with positive coordinates for axes 1 and 2 (Fig. 4), with low mean concentrations of nutrients, low turbidity, and low chl a concentrations (Fig. 5, Table 4). Among the years, the positions of the environmental variables and species compositions of the submerged macrophyte communities at AYR showed minor movements in the compromise factor map, suggesting stable environmental variables and species assemblages with only small fluctuations over the study period (1999-2015). Such minor fluctuations were indeed confirmed by very low standard deviations (SD) of water column variables (Table 4). The species composition was constant, dominated by $Z$. noltei and $A$. acetabulum, although total vegetation cover showed significant fluctuations (Fig. 6a). A minimum vegetation cover of $41 \%$ was observed in 2005, corresponding to a biomass (mean $\pm \mathrm{SD}$ ) of $Z$. noltei of $62.2 \pm 76.7 \mathrm{~g} \mathrm{~m}^{-2}$, compared to a biomass of $Z$. noltei of $767 \pm 492 \mathrm{~g} \mathrm{~m}^{-2}$ observed in 1999. Furthermore, Z. marina presence strongly fluctuated: it was observed at $86 \%$ (12 out of 14) of the benthic stations in 2002 and was only observed at 2 stations in 2005 and 1 station in 2007 (out of 14 stations). In the following study years (2010 and 2013), the total vegetation cover (see Fig. 6a for total cover before and after 2005) and the frequency of occurrence of $Z$. marina returned to values observed before 2005.

Before 2003, BGN was qualified as eutrophic (see Tables 3 \& 4). In the compromise factor map, this lagoon sector moved from slightly eutrophic conditions towards oligotrophic conditions close to those observed in AYR. Before 2003, nutrient concentrations in BGN were low compared to those observed in MEW and GRC. Since the implementation of management actions for sewage treatment in 2003 on the Bages watershed, levels of TN, TP, and 

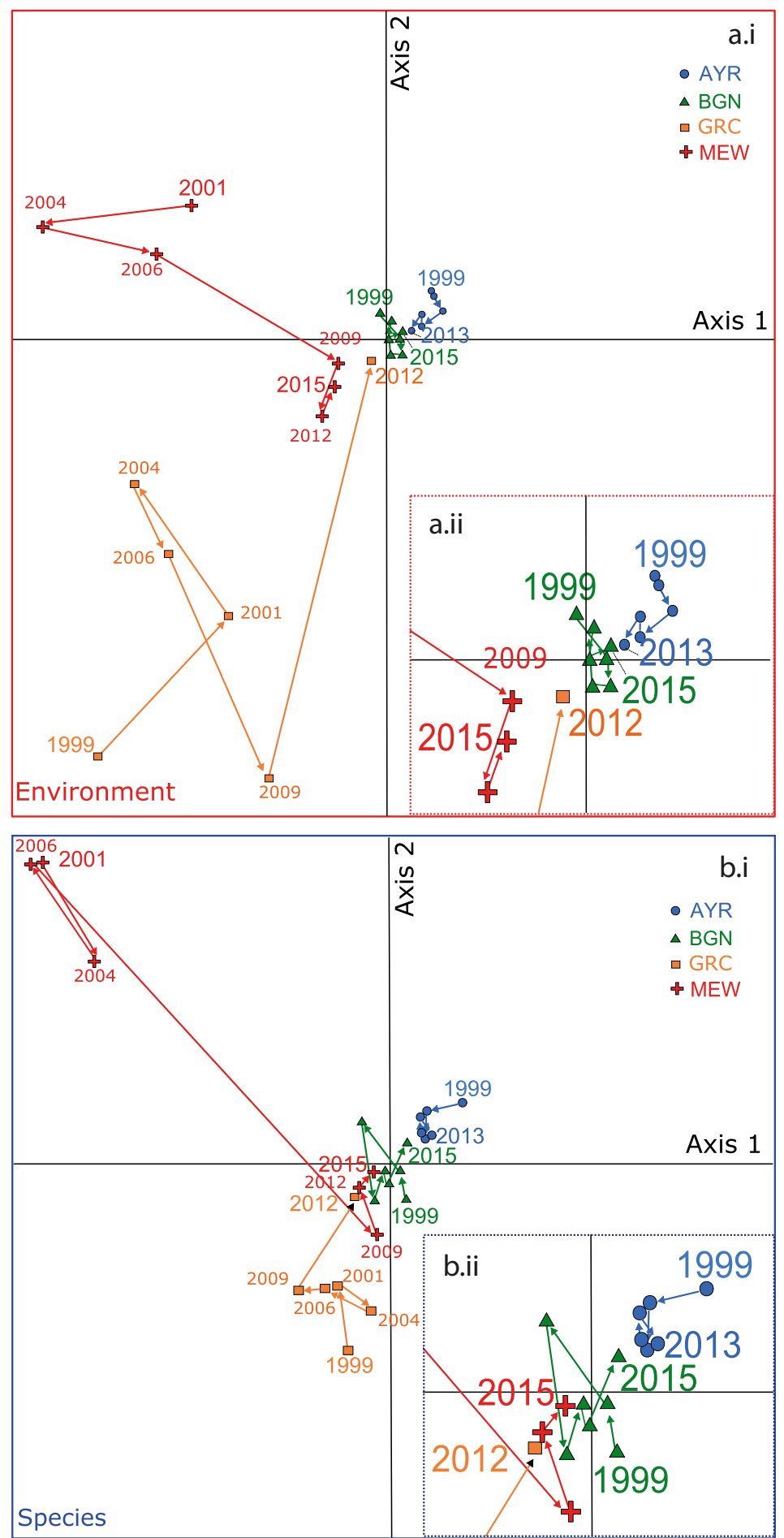

Fig. 4. Trajectories of the STATICO analysis showing the temporal dynamics of (a.i) the environmental parameters and (b.i) macrophyte species in the sectors of Ayrolle (AYR, blue dots), Bages North (BGN, green triangles), Grec (GRC, orange squares) and Méjean West (MEW, red crosses) in the compromise factor map. For each sector, the sampling dates are linked by arrows indicating the direction of the trajectory over time. The inserts (a.ii) and (b.ii) show enlargements focusing on the trajectories close to the origin of the compromise factor map
$\mathrm{PO}_{4}$ in BGN decreased significantly (Wilcoxon test, p < 0.05), by $29 \%, 58 \%$ and $80 \%$, respectively. Simultaneously, chl a decreased significantly by $50 \%$ (Wilcoxon test, $\mathrm{p}<0.05$ ) (Fig. 5, Table 4). In contrast, dissolved inorganic nitrogen and turbidity showed no significant differences before and after the implementation of management actions. Concomitant with the changes in the water column, we observed a change in the macrophyte community composition over the study period. From 1999 to 2005, the vegetation of BGN was dominated by the species $U$. rigida, G. gracilis, G. bursa-pastoris and C. vagabunda. The mean $( \pm \mathrm{SD})$ total vegetation cover decreased from $89.1 \pm 13.6 \%$ in 2002 to $68.5 \pm 34.8 \%$ in 2005 (Fig. 6b). In 2005, G. gracilis represented the highest average biomass of the sector $\left(117 \pm 154 \mathrm{~g} \mathrm{~m}^{-2}\right)$ compared with $C$. vagabunda $\left(6.1 \pm 5.1 \mathrm{~g} \mathrm{~m}^{-2}\right)$ and $Z$. noltei $\left(4.8 \pm 15.1 \mathrm{~g} \mathrm{~m}^{-2}\right)$. In the same year, the seagrass $Z$. noltei declined strongly and $Z$. marina disappeared. In addition, a lack of vegetation was observed in some benthic stations. In 2007, a recovery of $Z$. marina was observed in 2 stations and the occurrence of Zostera spp. started to increase and finally, in 2013, this genus was found at all the benthic stations. In 2013 and 2015, the mean total vegetation cover reached more than $70 \%$ (Fig. 6b). Furthermore, the species richness increased from 4 to 12 species between 2005 and 2015.

Before 2005, MEW and GRC were clearly qualified as hypertrophic. The first sampling years of MEW and GRC were projected to the left-most side of the compromise factor map both for environment and species composition (Fig. 4). Nevertheless, a strong difference was observed between MEW and GRC. This difference was related to the absence of submerged aquatic vegetation (i.e. bare sediments), to higher concentration of chl $a$ in MEW before 2006, and to particularly high values of dissolved inorganic nitrogen in GRC (Figs. 3 \& 5). Both MEW and GRC trajectories for environment parameters moved toward the center of the compromise factor map (Fig. 4). After 2005, in both sectors, TN, $\mathrm{TP}$, and chl a dropped significantly (Wilcoxon test, $\mathrm{p}<0.05$ ) by more than $55 \%, \sim 60 \%$ and $>79 \%$, respectively (Table 4 ). The turbidity levels also showed a significant change after 

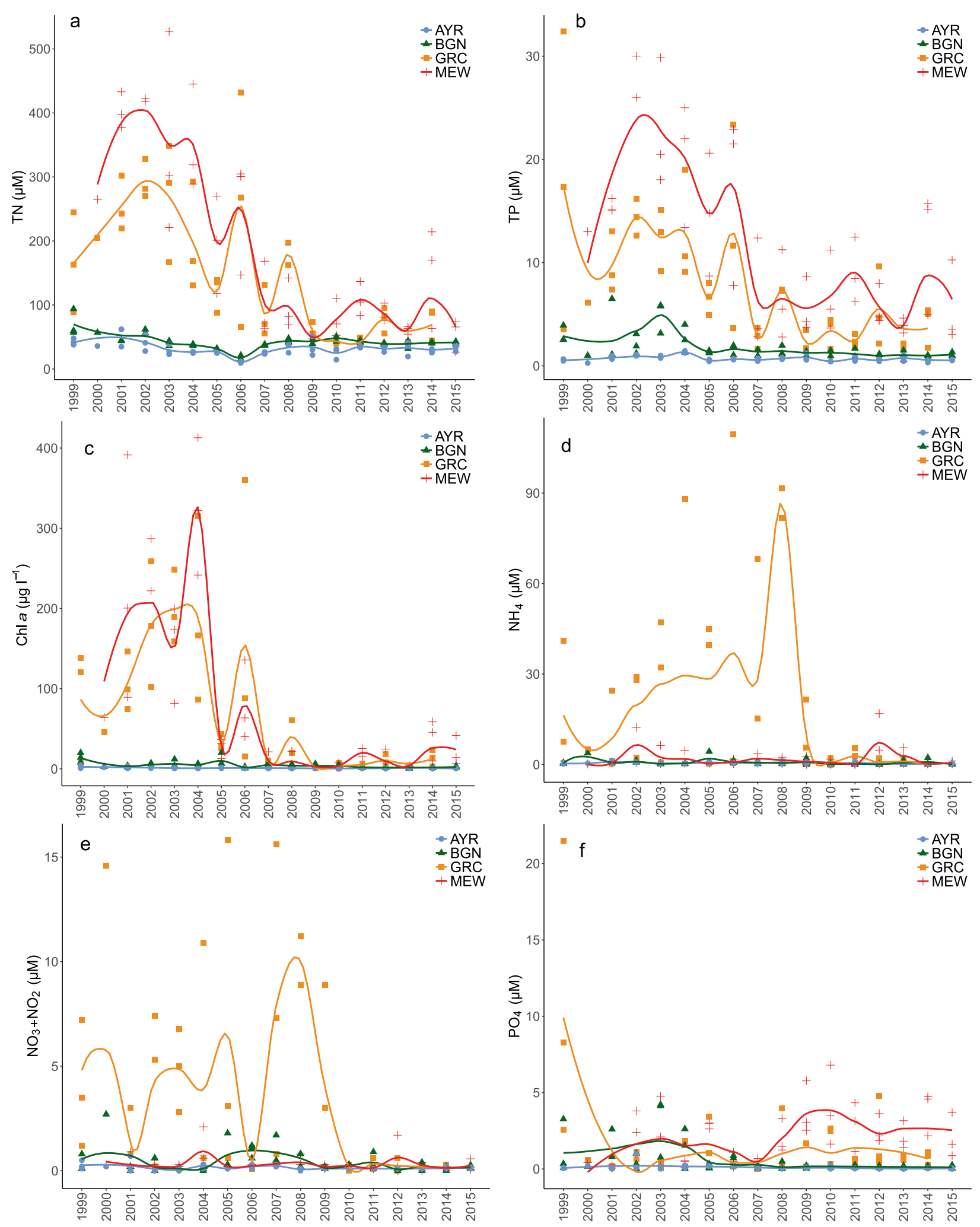

Fig. 5. Time courses of (a) total nitrogen (TN), (b) total phosphorus (TP), (c) chlorophyll a (chl a), (d) ammonium (NH a $_{4}$, (e) nitrate plus nitrite $\left(\mathrm{NO}_{3}+\mathrm{NO}_{2}\right)$ and (f) phosphate $\left(\mathrm{PO}_{4}\right)$, between the summers of 1999 and 2015 for Ayrolle (AYR, blue dots), Bages North (BGN, green triangle), Grec (GRC, orange squares), and Méjean West (MEW, red crosses). For each graph, the LOESS regression line for each lagoon sector is shown 
a

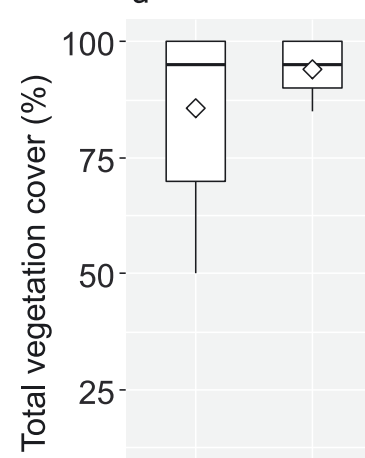

0
AYR

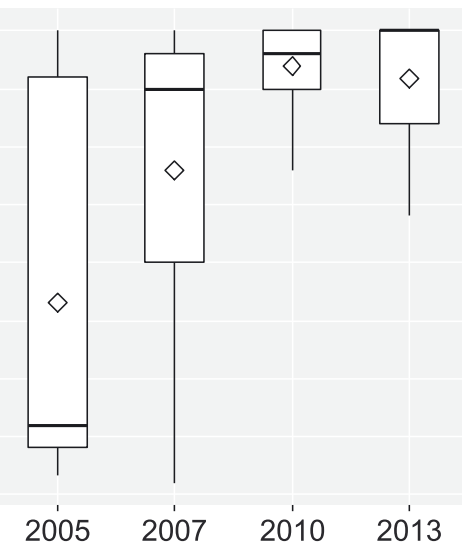

GRC

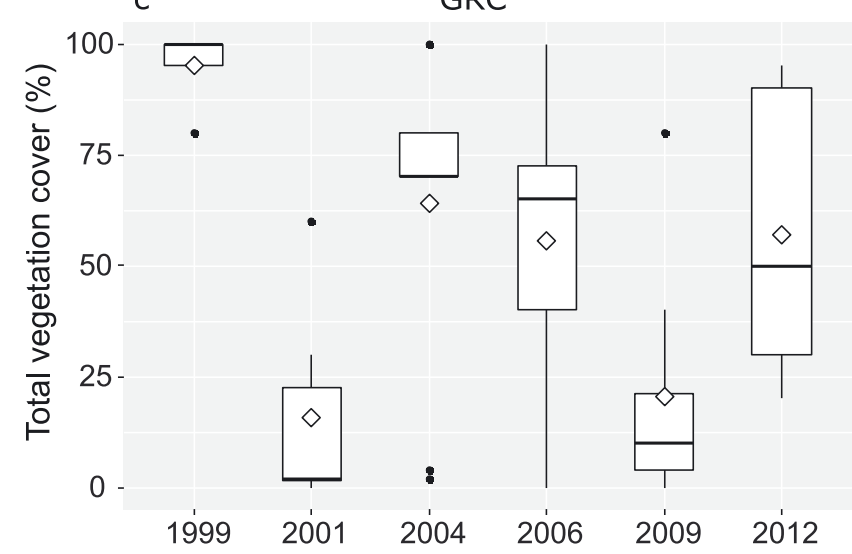

b

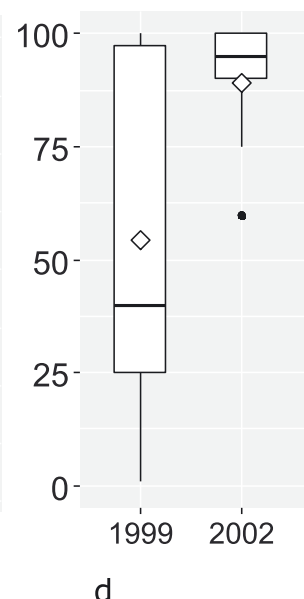

BGN

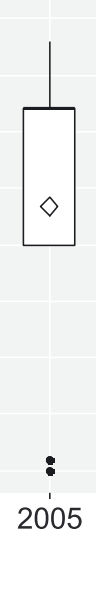

\section{BGN}

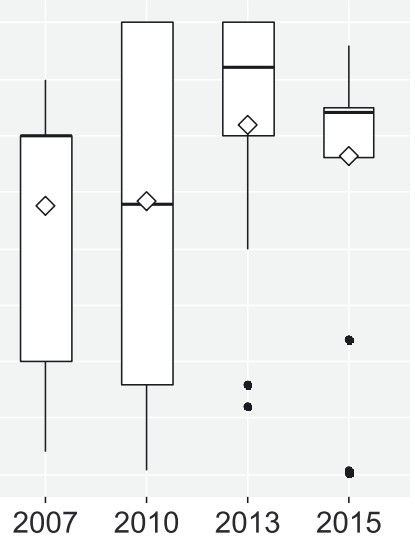

100

\section{MEW}

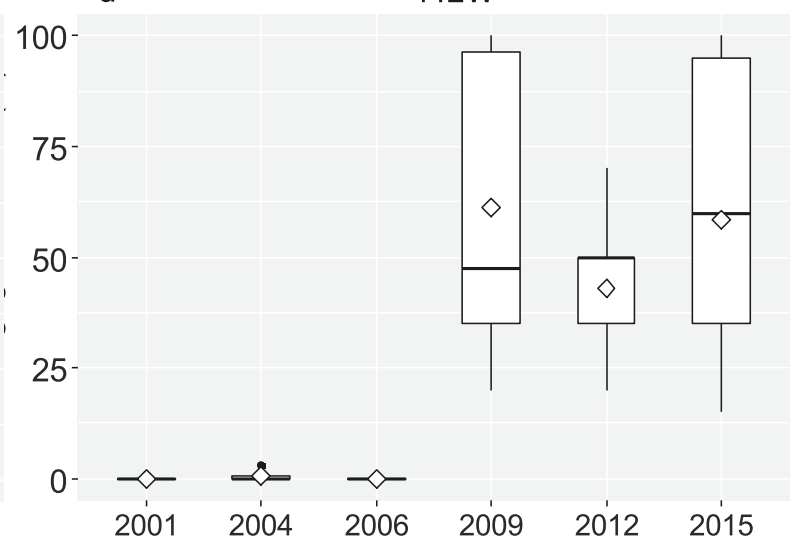

Fig. 6. Time course of the mean total vegetation cover in (a) Ayrolle (AYR), (b) Bages North (BGN), (c) Grec (GRC) and (d) Méjean West (MEW). Box and whiskers plots from spring data in all benthic stations. The whiskers represent the 5th and the 95th percentiles, the outer edges of the boxes represent the 25th and 75th percentiles, and the horizontal line within the boxes represents the median. The diamond symbols represent the means

2005 with a decline from 22.4 NTU and 27.1 NTU, in GRC and MEW, respectively, to $\sim 15$ NTU (Wilcoxon test, $\mathrm{p}<0.05)$.

In MEW the trajectory of species (Fig. 4b) showed a change from non-vegetated (bare sediment) to a macroalgal community comprising algae of the genera Ulva, Gracilaria and Chaetomorpha (Fig. 7a). No submerged vegetation was observed in 2001 and 2006, only some thalli of $U$. clathrata and $G$. gracilis were present in 1 station in 2004 (Fig. 7a). In 2009, an emergence of species was observed with a mean total vegetation cover higher than $60 \%$ (Fig. 6d). U. rigida was the dominant species followed by G. gracilis (Fig. 7a). From 2009 to 2015, the mean cover of $U$. rigida declined by more than $90 \%$. In 2012 and 2015, Gracilaria spp. and C. aerea became the dominant species. The red algae C. capillaris and Solieria chordalis (C. Agardh) J. Agardh also emerged in 2015. In 2015, macroalgae species were present at all benthic stations.
Between 2009 and 2015, the species richness increased from 5 to 9 species.

For the GRC sector, the trajectory of species also moved toward the center of the compromise factor map. Submerged aquatic vegetation was present during the entire monitoring period. From 1999 to 2009, the green algae $U$. rigida and $U$. clathrata were the only species observed in GRC (Fig. 7b). During this period, important fluctuations of the mean vegetation cover Ulva spp. (Figs. 6c \& 7b) and biomass were observed. In 1999, the mean vegetal cover of $U$. rigida was $95.0 \pm 8.7 \%$ for all benthic stations associated with a high average biomass $\left(141 \pm 118 \mathrm{~g} \mathrm{~m}^{-2}\right)$. Afterwards, the mean total dropped in 2009 to reach $20.4 \pm 27.1 \%$ (Fig. 7b). Important reductions of nutrient loads were realized in 2 steps, i.e. in 2005 and in 2009. An important change of the macrophytes community was observed in 2012 with the decline of $U$. rigida (mean cover: $3.2 \pm 6.3 \%$ in 2012) and the appearance of 3 new species: the red algae G. bursa- 


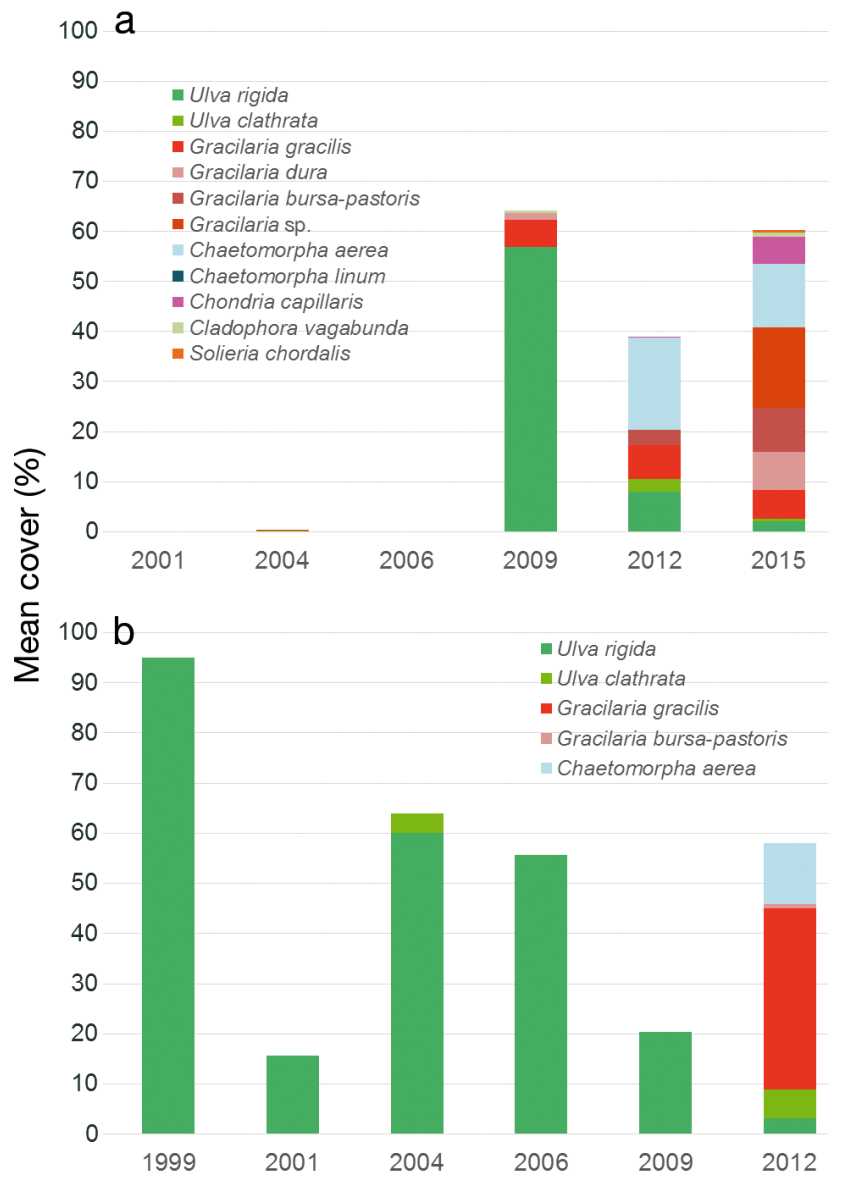

Fig. 7. Change in the mean cover (\%) of macrophyte species over time in (a) Méjean West (MEW) and (b) Grec (GRC)

pastoris, G. gracilis and the green algae C. aerea (Fig. 7b). In 2012, G. gracilis and C. aerea were dominant with a mean cover of $36.2 \pm 22.6 \%$ and $12.2 \pm$ $6.3 \%$, respectively.

\subsection{Variation of organic matter and $\mathbf{N}$ and $P$ contents in sediments}

Averaged over the entire period OM content (mean $\pm \mathrm{SD}$ ) was lowest in AYR and highest in GRC, $3.0 \pm$ $1.6 \%$ and $11.0 \pm 2.0 \%$, respectively (Kruskal-Wallis test, $\mathrm{p}<0.05)$. TNsed and TPsed were lowest in AYR, $0.81 \pm 0.53 \mathrm{~g} \mathrm{~kg}^{-1}$ and $268 \pm 79.5 \mathrm{mg} \mathrm{kg}^{-1}$, respectively, and highest in MEW, $3.9 \pm 0.89 \mathrm{~g} \mathrm{~kg}^{-1}$ and 869 $\pm 99.6 \mathrm{mg} \mathrm{kg}^{-1}$, respectively (Kruskal-Wallis test, $\mathrm{p}<$ 0.05). Between 1999 and 2010, we observed a 25-30\% TPsed decrease in AYR and BGN from $314 \pm$ $78.2 \mathrm{mg} \mathrm{kg}^{-1}$ to $221 \pm 79.3 \mathrm{mg} \mathrm{kg}^{-1}$, and from $519 \pm$ $111 \mathrm{mg} \mathrm{kg}^{-1}$ to $385 \pm 86.3 \mathrm{mg} \mathrm{kg}^{-1}$, respectively (Wilcoxon tests, $\mathrm{p}<0.05$ ). During the entire study period, OM content and TNsed did not vary significantly in the 4 studied lagoons and TPsed showed no significant variation in MEW and GRC.

\section{DISCUSSION}

In this study, we aimed to describe a general pattern for re-oligotrophication trajectories for the macrophyte communities all the way from hypertrophy to oligotrophy. Such a complete trajectory that was not observed for a single lagoon in our database, can be inferred by combining trajectories observed in the compromise factor map for different lagoons (Fig. 4). Hence, after nutrient reduction, the trajectories of the 2 hypertrophic lagoons (Méjean and Grec) and the eutrophic lagoon (North Bages) were all directed towards the oligotrophic conditions as observed in Ayrolle lagoon (Fig. 4). Placed hypertrophic and oligotrophic conditions end to end, we postulate that the general pattern for re-oligotrophication trajectories in Mediterranean coastal lagoons is described by the following sequence, each punctuated by a regime shift: (1) bare non-vegetated sediments, phytoplankton-dominated state; (2) opportunistic macroalgae; (3) seagrass and perennial macroalgae dominated state (Fig. 8). However, we did not observe the second regime shift for Méjean and Grec lagoons, which remained in the macroalgal dominated state. The studied 10 -yr re-oligotrophication trajectory was probably not long enough for these lagoons, which had been very strongly impacted by nutrient over-enrichment for multiple decades.

\subsection{Relationships between water column variables and macrophyte assemblages}

Under oligotrophic conditions, Mediterranean lagoons are characterized by high species richness and dominated by perennial macrophytes such as the macroalgae $A$. acetabulum and $V$. aegagropila and the seagrasses $Z$. marina and/or $Z$. noltei. Thanks to their ability to absorb nutrients in the sediment with their root system, seagrasses are particularly adapted to low nutrient levels in the water column (Romero et al. 2006). Under more eutrophic and in nearly hypertrophic conditions, these lagoons are dominated by free-floating macroalgae such as Ulva spp., Gracilaria spp. and C. area. Worldwide, these species bloom in response to increased anthropogenic nutrient inputs to coastal waters worldwide (Schramm \& Nienhuis 1996, Kennish \& Paerl 2010, Le Fur et al. 


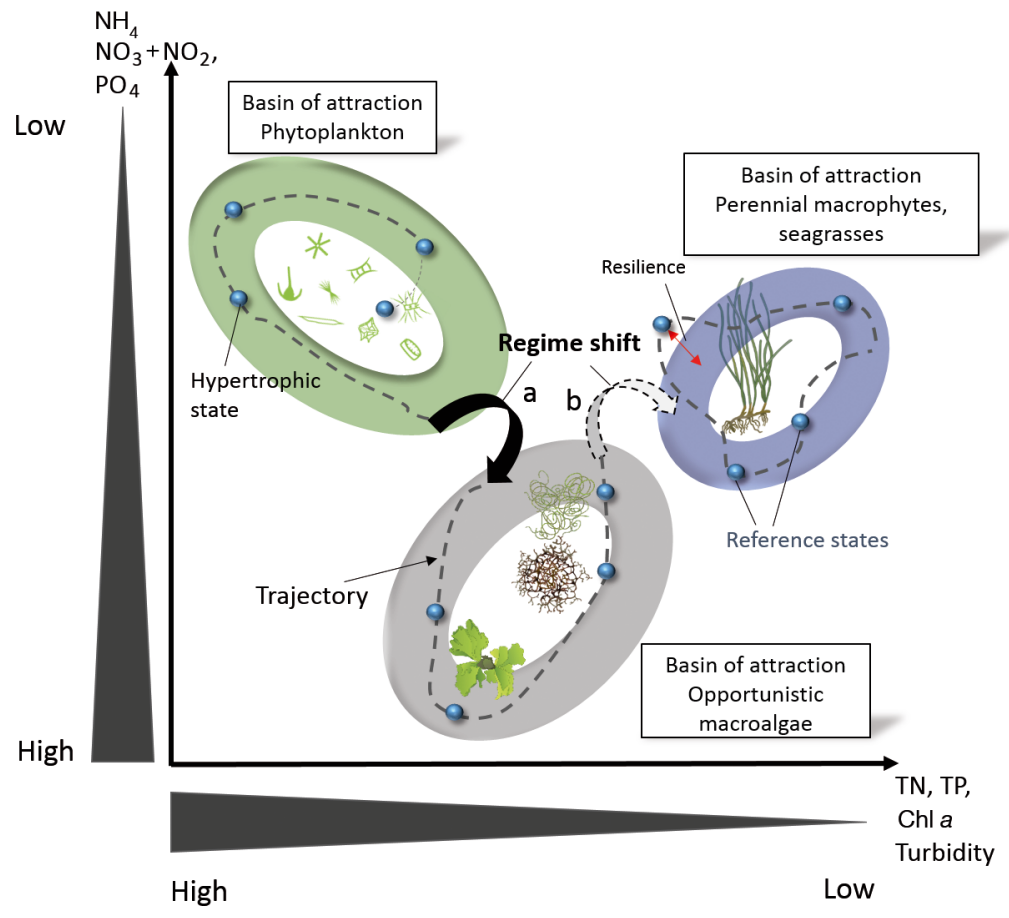

Fig. 8. Illustration of ecosystem states and regime shifts along re-oligotrophication trajectories in coastal lagoons. The ellipses represent the 3 basins of attraction that we identified, i.e. the 3 states dominated by (1) phytoplankton with non-vegetated sediments, (2) opportunistic macroalgae, and (3) perennial macroalgae and angiosperms. Within an attraction basin the vegetation assemblages may vary in terms of species composition and densities due to variations of environmental conditions. The small blue spheres represent the different ecosystem states and the stippled lines their trajectories according to the temporal sequence of these states. The sphere moves between basins of attraction following changes in nutrient concentration. The sequence during re-oligotrophication is characterized by $(\mathrm{a}$, black arrow) a shift from phytoplankton to opportunistic macroalgae; (b, dashed grey arrow) a shift from opportunistic macroalgae to perennial macrophytes. The second regime shift was not observed in our study. Inspired by Tett et al. (2013). Symbols courtesy of the Integration and Application Network, University of Maryland Center for Environmental Science (ian.umces. edu/symbols/)

2018). The high affinity of Ulva spp. for nitrate and ammonium and their high growth rates give them a competitive advantage compared with more slowly growing species such as seagrasses (Pedersen \& Borum 1997). Under hypertrophic conditions with continuously high nutrient inputs, phytoplankton is often the main primary producer, preventing macroalgal growth due to shading (Sand-Jensen \& Borum 1991, Duarte 1995). This was clearly the case for the Méjean lagoon before 2006. Hence, this is also consistent with the schematic model of Schramm (Schramm \& Nienhuis 1996, Schramm 1999) and in situ observations made by several authors in lagoons, and more generally in coastal ecosystems (Sand-Jensen \& Borum 1991, Duarte 1995, Burkholder et al. 2007, Viaroli et al. 2008, Le Fur et al.
2018). Nevertheless, intense eutrophication is not always associated with macroalgal decline (De Vries et al. 1996, Cebrian et al. 2014). For example, in more shallow lagoons, the effect of shading by phytoplankton is reduced and high flushing in lagoons with short residence times may restrict the accumulation of phytoplankton biomass. The former appears to be the case for the shallow Grec lagoon, where hypertrophic conditions co-occur with a predominance of macroalgae.

\subsection{Linking re-oligotrophication trajectories of macrophytes with ecosystem theory}

Ecosystem theory predicts that different ecosystem states are the result of attraction basins that result from feedback loops between the biocenosis and the environmental conditions, when these include both positive and negative feedbacks (Walker et al. 2004). The shifts from one attraction basin to another, which is induced by forcing above a threshold level, are known as regime shifts in ecosystem theory. Thus, we recognize 3 major states for the lagoon ecosystem, each as attraction basins characterized by different assemblages of primary producers that can be plotted in the ecosystem state space. The re-oligotrophication trajectories can thus be described as regime shifts between these states, which are explained hereafter. The conditions in the hypertrophic Méjean lagoon before the reduction of the nutrient loading, were characterized by bare non-vegetated sediments and high phytoplankton densities reflected by high chl $a$, TN and TP concentrations and high turbidity. This corresponds clearly to an attraction basin (Fig. 8), as it has been described for hypertrophic lakes by Scheffer et al. (1993), where high turbidity in the water column results in insufficient light for benthic macrophytes. On the oligotrophic side, an attraction basin based on rooted angiosperms (seagrasses) and perennial macroalgae such as $A$. acetabulum and $V$. aegagropila (Fig. 8) is exemplified by Ayrolle lagoon (AYR). This lagoon exhibited small fluctuations both for water column variables and macrophyte composi- 
tion. Stronger fluctuations occurred for vegetation cover, particularly for Zostera spp., showing a decline of the coverage between 2002 and 2005 followed by a rapid recovery (Fig. 6). These variations show that the concept of an attraction basin describes the ecosystem state better for these oligotrophic conditions than stable equilibrium. The variations may be linked to natural changes (e.g. climatic variability) or to occasional and short-term pressure on this lagoon. Shortly after the reduction of the nutrient loadings, a regime shift was observed for the hypertrophic Méjean lagoon from the bare non-vegetated sediments, phytoplankton-dominated state to a dominance of opportunistic macroalgae. The decrease of chl a concentration by 1 order of magnitude we observed (Table 4) may have been concomitant to changes of phytoplankton composition from picoeukaryotic diatoms towards green algae dominance (e.g. small Chlorella-like algae) and dinophytes, which have been described by Leruste et al. (2016). The first species to proliferate after this regime shift was $U$. rigida succeeded later by other species such as Gracilaria spp., Chaetomorpha spp., Chondria capillaris and $S$. chordalis (Fig. 7). In the shallow hypertrophic Grec lagoon, U. rigida was present, albeit at fluctuating densities, throughout the entire $14-\mathrm{yr}$ period (Fig. 7). Hence, a third basin of attraction in these coastal lagoons corresponds to a dominance of opportunistic macroalgae. However, the factors driving macroalgal species blooms are still unclear. Thus, it is uncertain whether or not different secondary attraction basins exist within the macroalgal attraction basin. Studies on nitrogen nutrition and growth of Ulva and Gracilaria species, however, indicate differences between these genera. Ulva species have higher photosynthetic and growth rates and take up nitrogen more rapidly than Gracilaria (Fujita 1985, Anderson et al. 1996). Ulva has a limited capacity to store nitrogen and depends on a constant high ambient concentration to sustain high growth rates. Conversely, Gracilaria maintains a high growth rate even when ambient nitrogen levels are low: it can store nitrogen for longer periods and can persist when nitrogen levels are low or only sporadically high. But, its maximal growth rate under optimal conditions is lower than that of Ulva (Ryther et al. 1981, Bird et al. 1982, Rosenberg \& Ramus 1982, Anderson et al. 1996). Futhermore, the increasing $\mathrm{PO}_{4}$ availability could also favour Gracilaria as it may increase its photosynthetic rate (García Sánchez et al. 1996). Thus, with its ability to take up lower levels of nitrogen and to store it for long periods, Gracilaria may have a competitive advantage over Ulva when the nitrogen concentrations are frequently depleted and, thus, become a limiting factor for Ulva.

During our study period, we did not observe a regime shift in Méjean and Grec lagoons towards oligotrophic angiosperms. In 2015, these lagoons remained in the macroalgae-dominated state. The studied 10-yr re-oligotrophication trajectory was probably not long enough for these lagoons, which had been very strongly impacted by nutrient over-enrichment for multiple decades, with the sediment acting as an internal source of nutrients. Furthermore, the absence of seagrasses during the very long period of eutrophication could have resulted in a lack of propagules to facilitate recovery. In contrast, in the north sector of the Bages lagoon (BGN), we observed a shift from an opportunistic macroalgae assemblage (e.g. Gracilaria spp., Ulva spp.) before 2005 to a system dominated by Zostera species. In this sector, Z. noltei had never completely disappeared and, therefore, one could argue that this is indicative of the resilience of the seagrass dominated state than a regime shift.

When a system is resilient, it tends to stay in its attraction basin if the threshold of forcing or disturbance is not exceeded. An ecosystem can be resilient both in its degraded and non-degraded states. In this study, we observed a case of resilience of the angiosperm-dominated state for 2 lagoons (AYR and BGN). The rapid recovery of seagrass in these lagoons was probably due to the persistence of seagrasses, their dispersal characteristics as well as the protected nature of these lagoons. Similar examples of resilience have been observed in Thau lagoon (Plus et al. 2003) and Biguglia lagoon (Pasqualini et al. 2017), where the aquatic angiosperms naturally recovered within 1 yr after a dystrophic crisis (socalled 'malaïgue' in the Mediterranean lagoons), and relatively shortly (4-5 yr) after improvements in sewage treatment and hydrological management, respectively. Moreover, after previous declines seagrasses have shown rapid recovery in a number of cases, as long as propagules (seeds) are available.

On the other hand, the macroalgal-dominated state also appears to be very resilient both with respect to shifts towards the phytoplankton-dominated state and the angiosperm-dominated state, forced by eutrophication and oligotrophication, respectively.

\subsection{Recovery process, factors causing delay, and difficulties for achieving ecological quality targets}

The definition of 'recovery' has been well defined for management purposes as a return towards undis- 
turbed system state once the pressure has been reduced or eliminated (Tett et al. 2013). Recovery is

... the process of an ecosystem regaining its composition, structure and function relative to the levels identified for the reference ecosystem

(McDonald et al. 2016, p. 20). As noted by Lotze et al. (2011, p. 596),

... the aim might be to recover a population or an ecosystem to pre-disturbance conditions or its 'natural' state before human disturbance

However, in many studies, including the present one, the historical baseline is not known owing to a lack of historical data. In our study, we thus assumed that we could use the oligotrophic Ayrolle lagoon as a reference site as a recovery target. Therefore, management is currently aimed at pursuing re-oligotrophication trajectories. However, we have to be careful with the choice of this recovery target because, since according to the trophic classification of Nixon (1995), some coastal lagoons fall within the range of eutrophic, mesotrophic or oligotrophic conditions based on their natural conditions of nutrient inputs and residence times. Therefore, some lagoons will probably never reach oligotrophic conditions. Nonetheless, for those lagoons where a return to oligotrophic conditions is possible, the recovery of perennial macrophytes will probably be a long process. Hence, long-term monitoring is still needed to see if the system is able to recover by itself after reduction of nutrient loading, without additional measures (De Wit et al. 2017). However, several authors have suggested that most ecosystems have shown partial recovery and that time lag or hysteresis can delay the recovery response even after the reduction or suppression of the environmental pressure (see Duarte et al. 2015).

Nutrient reduction plans have often failed to return coastal ecosystems to the pre-disturbance state due to hysteresis and shifting baselines (Duarte et al. 2015). As our results show, high internal nutrient loads have accumulated in the sediment during the previous eutrophication periods. However, we only observed a reduction of TP, but not of TN in the sediment over the study period. The continuing nutrient fluxes from the sediment represent an internal load that may support phytoplankton growth (Richardson \& Jørgensen 1996) or macroalgal growth during reoligotrophication trajectories, thus delaying the recovery process. However, following the reduction of external nutrient loading, the decrease of phytoplankton biomass increases the light availability for benthic primary producers. Therefore, macrophytes become important once again and can accelerate the recovery process by re-oxygenating the sediment, intercepting the sediment-water column nutrient flux and temporarily retaining nutrients in plant biomass (McGlathery et al. 2007).

According to Duarte et al. (2015), recovery is believed to be dependent also on the connectivity between the degraded recovering and adjacent healthy ecosystems. Connectivity would allow the supply of propagules and colonizers (Pratt 1994) and will also impact other functional aspects through its influence on the resilience of ecosystems (Elliott et al. 2007).

In addition to internal loading and the lack of connectivity with healthy ecosystems, other factors can also limit the recovery, such as nutrient inputs from diffuse sources (e.g. agriculture), for which it is still difficult to assess the importance and which are difficult to manage effectively to achieve reduction. Hence, these diffuse nutrient sources may still contribute to maintain eutrophic conditions in several Mediterranean lagoons. In addition, Grec and Méjean lagoons are not directly connected to the sea but receive nutrient-rich waters from a canal ('Rhône to Sète' canal), which will hinder the quick recovery of these lagoons. Furthermore, coastal lagoons can be strongly affected by chemical contaminants (Munaron et al. 2012) and some of these compounds can impact the photosynthesis and the growth of macrophytes (Haynes et al. 2000, Chesworth et al. 2004). Physical factors such as sediment resuspension can also limit the recovery, by maintaining low water transparency and limiting light availability for macrophytes. Dense seagrass meadows stabilize the sediment by dissipating wave energy and promoting particle trapping, and hence improve water clarity (Widdows et al. 2008, Carr et al. 2010, Maxwell et al. 2017). But in the absence of vegetation, the sediment resuspension and consecutive high turbidity will limit the reestablishment of these rooted angiosperms. In addition, the historical states of the Méjean and Grec lagoons are not known. We do not know if rooted macrophytes were initially present at all stations in these lagoons. A recent study tested the potential presence of $Z$. noltei in the Méjean lagoon, by simulating oligotrophic conditions of the water column. This study showed that several areas of this lagoon were not able to harbor this species due to wind conditions and bottom shear stress (Ouisse et al. 2014). This highlights that, when the historical state of an ecosystem is unknown, the desired state may not be reached due to natural conditions even when pressures have been removed. 
Acknowledgements. This study was supported by a $\mathrm{PhD}$ grant for I.L.F., financed by Ifremer and the French Water Agency (Agence de l'Eau Rhône-Méditerranée-Corse). The authors thank the staff of the Ifremer laboratory (LER/LR) and all the people involved in the collection of the data on which this article is based. All the data used in this paper have been collected through the Lagoon Monitoring Network and the Water Framework Directive (WFD) monitoring, and additional studies (PNEC, INTERREG II/PNOC and RLC programs) carried out from 1998 to 2015.

\section{LITERATURE CITED}

Anderson RJ, Monteiro PMS, Levitt GJ (1996) The effect of localised eutrophication on competition between Ulva lactuca (Ulvaceae, Chlorophyta) and a commercial resource of Gracilaria verrucosa (Gracilariaceae, Rhodophyta). Hydrobiologia 326-327:291-296

Barbier EB, Hacker SD, Kennedy C, Koch EW, Stier AC, Silliman BR (2011) The value of estuarine and coastal ecosystem services. Ecol Monogr 81:169-193

Barnes RSK (1980) Coastal lagoons, the natural history of a neglected habitat. Cambridge University Press, Cambridge

Bec B, Collos Y, Souchu P, Vaquer A and others (2011) Distribution of picophytoplankton and nanophytoplankton along an anthropogenic eutrophication gradient in French Mediterranean coastal lagoons. Aquat Microb Ecol 63:29-45

Bird KT, Habig C, DeBusk T (1982) Nitrogen allocation and storage patterns in Gracilaria tikvahiae (Rhodophyta). J Phycol 18:344-348

Borja Á, Dauer DM, Elliott M, Simenstad CA (2010) Medium- and long-term recovery of estuarine and coastal ecosystems: patterns, rates and restoration effectiveness. Estuaries Coasts 33:1249-1260

Burkholder JM, Tomasko DA, Touchette BW (2007) Seagrasses and eutrophication. J Exp Mar Biol Ecol 350:46-72

Carr J, D'Odorico P, McGlathery K, Wiberg P (2010) Stability and bistability of seagrass ecosystems in shallow coastal lagoons: role of feedbacks with sediment resuspension and light attenuation. J Geophys Res Biogeosci 115:G03011

Cebrian J, Corcoran D, Lartigue J (2014) Eutrophicationdriven shifts in primary producers in shallow coastal systems: implications for system functional change. Estuaries Coasts 37:180-197

Cépralmar (2006) Défi eutrophisation des lagunes littorales du Languedoc-Roussillon-Etude réalisée dans le cadre du 8ème programme de l'Agence de l'Eau RhôneMéditerranée et Corse. Cépralmar, Montpellier

Charlier RH, Lonhienne $\mathrm{T}$ (1996) The management of eutrophicated waters. In: Schramm W, Nienhuis PN (eds) Marine benthic vegetation. Springer, Berlin, p 45-78

* Chesworth JC, Donkin ME, Brown MT (2004) The interactive effects of the antifouling herbicides Irgarol 1051 and Diuron on the seagrass Zostera marina (L.). Aquat Toxicol 66:293-305

* Cloern JE (2001) Our evolving conceptual model of the coastal eutrophication problem. Mar Ecol Prog Ser 210: 223-253

Costanza R, d'Arge R, de Groot R, Farber S and others (1997) The value of the world's ecosystem services and natural capital. Nature 387:253-260
* De Vries I, Philippart CJM, De Groodt EG, van der Tol MWM (1996) Coastal eutrophication and marine benthic vegetation: a model analysis. In: Schramm W, Nienhuis PN (eds) Marine benthic vegetation. Ecol Stud, Vol 123. Springer Science \& Business Media, Berlin, p 79-113

De Wit R, Rey-Valette H, Balavoine J, Ouisse V, Lifran R (2017) Restoration ecology of coastal lagoons: new methods for the prediction of ecological trajectories and economic valuation. Aquat Conserv 27:137-157

Dion P, Bozec SL (1996) The French Atlantic coasts. In: Schramm W, Nienhuis P (eds) Marine benthic vegetation: recent changes and the effects of eutrophication. Ecol Stud, Vol 123. Springer Science \& Business Media, Berlin, p 251-264

*Dolédec S, Chessel D (1994) Co-inertia analysis: an alternative method for studying species-environment relationships. Freshw Biol 31:277-294

Dray S, Dufour AB (2007) The ade4 package: implementing the duality diagram for ecologists. J Stat Softw 22:1-20

* Duarte CM (1995) Submerged aquatic vegetation in relation to different nutrient regimes. Ophelia 41:87-112

* Duarte CM, Cebrián J (1996) The fate of marine autotrophic production. Limnol Oceanogr 41:1758-1766

Duarte CM, Borja A, Carstensen J, Elliott M, Krause-Jensen D, Marbà N (2015) Paradigms in the recovery of estuarine and coastal ecosystems. Estuaries Coasts 38:1202-1212

* Elliott M, Burdon D, Hemingway KL, Apitz SE (2007) Estuarine, coastal and marine ecosystem restoration: confusing management and science-a revision of concepts. Estuar Coast Shelf Sci 74:349-366

Facca C, Ceoldo S, Pellegrino N, Sfriso A (2014) Natural recovery and planned intervention in coastal wetlands: Venice lagoon (northern Adriatic Sea, Italy) as a case study. Sci World J 2014:968618

Fiandrino A, Ouisse V, Dumas F, Lagarde F and others (2017) Spatial patterns in coastal lagoons related to the hydrodynamics of seawater intrusion. Mar Pollut Bull 119:132-144

*Flindt MR, Pardal MÂ, Lillebø AI, Martins I, Marques JC (1999) Nutrient cycling and plant dynamics in estuaries: a brief review. Acta Oecol 20:237-248

F Fujita RM (1985) The role of nitrogen status in regulating transient ammonium uptake and nitrogen storage by macroalgae. J Exp Mar Biol Ecol 92:283-301

*García Sánchez MJ, Fernández JA, Niell FX (1996) Photosynthetic response of $\mathrm{P}$ deficient Gracilaria tenuistipitata under two different phosphate treatments. Physiol Plant 96:601-606

Guiry MD, Guiry GM (2016) AlgaeBase. World-wide electronic publication. National University of Ireland, Galway. www.algaebase.org/ www.algaebase.org/

Harlin MM (1995) Changes in major plant groups following nutrient enrichment. In: McComb AJ (ed) Eutrophic shallow estuaries and lagoons. CRC Press, Boca Raton, FL, p 173-187

*Haynes D, Ralph P, Prange J, Dennison B (2000) The impact of the herbicide Diuron on photosynthesis in three species of tropical seagrass. Mar Pollut Bull 41:288-293

*Human LRD, Snow GC, Adams JB, Bate GC, Yang SC (2015) The role of submerged macrophytes and macroalgae in nutrient cycling: a budget approach. Estuar Coast Shelf Sci 154:169-178

Ifremer (2007) Réseau de suivi lagunaire du LanguedocRoussillon. Bilan des résultats 2006. Rapport RSL07/2007. https://archimer.ifremer.fr/doc/00118/22926/ 
Kennish MJ, Paerl HW (2010) Coastal lagoons: critical habitats of environmental change. CRC Press, Boca Raton, FL

Kidé SO, Manté C, Dubroca L, Demarcq H, Mérigot B (2015) Spatio-temporal dynamics of exploited groundfish species assemblages faced to environmental and fishing forcings: insights from the Mauritanian exclusive economic zone. PLOS ONE 10:e0141566

Kjerfve B (1994) Coastal lagoons. In: Kjerfve B (ed) Coastal lagoon processes. Elsevier Oceanogr Ser, Vol 60. Elsevier Science, Amersterdam, p 1-8

Le Fur I, De Wit R, Plus M, Oheix J, Simier M, Ouisse V (2018) Submerged benthic macrophytes in Mediterranean lagoons: distribution patterns in relation to water chemistry and depth. Hydrobiologia 808:175-200

Lefcheck JS, Orth RJ, Dennison WC, Wilcox DJ and others (2018) Long-term nutrient reductions lead to the unprecedented recovery of a temperate coastal region. Proc Natl Acad Sci USA 115:3658-3662

Leruste A, Malet N, Munaron D, Derolez V and others (2016) First steps of ecological restoration in Mediterranean lagoons: shifts in phytoplankton communities. Estuar Coast Shelf Sci 180:190-203

Lloret J, Marín A (2009) The role of benthic macrophytes and their associated macroinvertebrate community in coastal lagoon resistance to eutrophication. Mar Pollut Bull 58:1827-1834

* Lloret J, Marín A (2011) The contribution of benthic macrofauna to the nutrient filter in coastal lagoons. Mar Poll Bull 62:2732-2740

Lotze HK, Coll M, Magera AM, Ward-Paige C, Airoldi L (2011) Recovery of marine animal populations and ecosystems. Trends Ecol Evol 26:595-605

* Lyons DA, Arvanitidis C, Blight AJ, Chatzinikolaou E and others (2014) Macroalgal blooms alter community structure and primary productivity in marine ecosystems. Glob Change Biol 20:2712-2724

Mann KH (1973) Seaweeds: their productivity and strategy for growth. Science 182:975

Maxwell PS, Eklöf JS, van Katwijk MM, O'Brien KR and others (2017) The fundamental role of ecological feedback mechanisms for the adaptive management of seagrass ecosystems - a review. Biol Rev Camb Philos Soc 92: $1521-1538$

* McCrackin ML, Jones HP, Jones PC, Moreno-Mateos D (2017) Recovery of lakes and coastal marine ecosystems from eutrophication: a global meta-analysis. Limnol Oceanogr 62:507-518

McDonald T, Jonson J, Dixon KW (2016) National standards for the practice of ecological restoration in Australia. Restor Ecol 24:S4-S32

McGlathery KJ, Sundbäck K, Anderson IC (2007) Eutrophication in shallow coastal bays and lagoons: the role of plants in the coastal filter. Mar Ecol Prog Ser 348:1-18

Meinesz C, Derolez V, Bouchoucha M (2013) Base de données « pressions sur les lagunes méditérranéennes »analyse des liens état-pression. https://archimer.ifremer. fr/doc/00154/26496/24607.pdf

Mendes S, Fernández-Gómez MJ, Pereira MJ, Miranda Azeiteiro U, Galindo-Villardón MP (2012) An empirical comparison of canonical correspondence analysis and STATICO in the identification of spatio-temporal ecological relationships. J App Stat 39:979-994

Munaron D, Tapie N, Budzinski H, Andral B, Gonzalez JL (2012) Pharmaceuticals, alkylphenols and pesticides in Mediterranean coastal waters: results from a pilot survey using passive samplers. Estuar Coast Shelf Sci 114:82-92

Neveux J, Lantoine F (1993) Spectrofluorometric assay of chlorophylls and phaeopigments using the least squares approximation technique. Deep Sea Res I 40:1747-1765

Nixon SW (1995) Coastal marine eutrophication: a definition, social causes, and future concerns. Ophelia 41: 199-219

* Orth RJ, Carruthers TJB, Dennison WC, Duarte CM and others (2006) A global crisis for seagrass ecosystems. Bioscience 56:987-996

Ouisse V, Perron C, Fiandrino A, Rochette S (2014) Rôle des macrophytes dans la restauration des milieux lagunaires: distribution spatiale de Zostera noltei (MARES1). ODE/ UL/LERLR 14-21. Ifremer, Sète

* Pasqualini V, Derolez V, Garrido M, Orsoni V and others (2017) Spatiotemporal dynamics of submerged macrophyte status and watershed exploitation in a Mediterranean coastal lagoon: understanding critical factors in ecosystem degradation and restoration. Ecol Eng 102:1-14

* Pedersen MF, Borum J (1997) Nutrient control of estuarine macroalgae: growth strategy and the balance between nitrogen requirements and uptake. Mar Ecol Prog Ser 161:155-163

*Plus M, Deslous-Paoli JM, Dagault F (2003) Seagrass (Zostera marina L.) bed recolonisation after anoxia-induced full mortality. Aquat Bot 77:121-134

* PNR (Parc Naturel Régional de la Narbonnaise en Méditerranée) (2011) Bulletin de l'observatoir du parc naturel régional. Spécial suivi des stations d'épuration- étang de Bages-Sigean Résultats 2009. No. 7, January 2011. www. parc-naturel-narbonnaise.fr/actions-parc/environnement/ lagunes-zones-humides/observatoire-des-etangs

Pratt JR (1994) Artificial habitats and ecosystem restoration: managing for the future. Bull Mar Sci 55:268-275

R Core Team (2018) R: a language and environment for statistical computing. R foundation for Statistical Computing, Vienna. www.R-project.org/

Richardson K, Jørgensen BB (1996) Eutrophication: definition, history and effects. In: Jørgensen BB, Richardson K (eds) Eutrophication in coastal marine ecosystems. American Geophysical Union, Washington, DC, p 1-19

Riemann B, Carstensen J, Dahl K, Fossing H and others (2016) Recovery of danish coastal ecosystems after reductions in nutrient loading: a holistic ecosystem approach. Estuaries Coasts 39:82-97

Romero J, Lee KS, Perez M, Mateo MA, Alcoverro T (2006) Nutrient dynamics in seagrass ecosystems. In: Larkum AWD, Orth RJ, Duarte C (eds) Seagrasses: biology, ecology and conservation, Vol 16. Springer, Dordrecht, p 227-254

Rosenberg C, Ramus J (1982) Ecological growth strategies in the seaweeds Gracilaria foliifera (Rhodophyceae) and Ulva sp. (Chlorophyceae): soluble nitrogen and reserve carbohydrates. Mar Biol 66:251-259

* Rysgaard S, Risgaard-Petersen N, Sloth NP (1996) Nitrification, denitrification, and nitrate ammonification in sediments of two coastal lagoons in Southern France. Hydrobiologia 329:133-141

Ryther JH, Corwin N, DeBusk TA, Williams LD (1981) Nitrogen uptake and storage by the red alga Gracilaria tikvahiae (McLachlan, 1979). Aquaculture 26:107-115

Sand-Jensen K, Borum J (1991) Interactions among phytoplankton, periphyton, and macrophytes in temperate freshwaters and estuaries. Aquat Bot 41:137-175 
Scheffer M, Hosper SH, Meijer ML, Moss B, Jeppesen E (1993) Alternative equilibria in shallow lakes. Trends Ecol Evol 8:275-279

Schramm W (1999) Factors influencing seaweed responses to eutrophication: some results from EU-project EUMAC. J Appl Phycol 11:69-78

Schramm W, Nienhuis P (1996) Marine benthic vegetation: recent changes and the effects of eutrophication. Ecol Stud, Vol 123. Springer Science \& Business Media, Berlin

Simier M, Blanc L, Pellegrin F, Nadris D (1999) Approche simultanée de $K$ couples de tableaux: application à l'étude des relations pathologie végétale-environnement. Rev Stat Appl 47:31-46

Souchu P, Bec B, Smith VH, Laugier T and others (2010) Patterns in nutrient limitation and chlorophyll a along an anthropogenic eutrophication gradient in French Mediterranean coastal lagoons. Can J Fish Aquat Sci 67:743-753

Tett P, Gowen RJ, Painting SJ, Elliott M and others (2013) Framework for understanding marine ecosystem health. Mar Ecol Prog Ser 494:1-27

Thioulouse J, Simier M, Chessel D (2004) Simultaneous analysis of a sequence of paired ecological tables. Ecology 85:272-283

Tsiamis K, Panayotidis P, Salomidi M, Pavlidou A, Kleinteich J, Balanika K, Küpper FC (2013) Macroalgal community response to re-oligotrophication in Saronikos Gulf. Mar Ecol Prog Ser 472:73-85

Editorial responsibility: Morten Pedersen, Roskilde, Denmark
Valiela I, McClelland J, Hauxwell J, Behr PJ, Hersh D, Foreman K (1997) Macroalgal blooms in shallow estuaries: controls and ecophysiological and ecosystem consequences. Limnol Oceanogr 42:1105-1118

*van der Heide T, van Nes EH, Geerling GW, Smolders AJP, Bouma TJ, van Katwijk MM (2007) Positive feedbacks in seagrass ecosystems: implications for success in conservation and restoration. Ecosystems 10:1311-1322

*Venice System (1958) The venice system for the classification of marine waters according to salinity. Limnol Oceanogr 3:346-347

* Viaroli P, Bartoli M, Giordani G, Naldi M, Orfanidis S, Zaldivar JM (2008) Community shifts, alternative stable states, biogeochemical controls and feedbacks in eutrophic coastal lagoons: a brief overview. Aquat Conserv 18:S105-S117

Walker B, Holling CS, Carpenter S, Kinzig A (2004) Resilience, adaptability and transformability in socialecological systems. Ecol Soc 9:5

Widdows J, Pope ND, Brinsley MD, Asmus H, Asmus RM (2008) Effects of seagrass beds (Zostera noltii and $Z$. marina) on near-bed hydrodynamics and sediment resuspension. Mar Ecol Prog Ser 358:125-136

WoRMS Editorial Board (2016) World register of marine species. Available from www.marinespecies.org at VLIZ. (accessed 16 November 2016)

Submitted: January 15, 2018 ; Accepted: November 4, 2018

Proofs received from author(s): December 13, 2018 